\title{
Article
}

\section{The New SWOT for a Sustainable World}

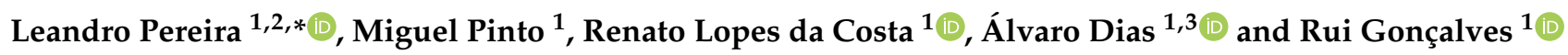 \\ 1 Business Research Unit, ISCTE Business School, 1649-026 Lisbon, Portugal; mtcpo1@iscte-iul.pt (M.P.); \\ Renato_jorge_costa@iscte-iul.pt (R.L.d.C.); alvaro.dias@ulusofona.pt (Á.D.); rahgs@iscte.pt (R.G.) \\ 2 Winning Lab, 1750-149 Lisbon, Portugal \\ 3 Universidade Lusófona de Humanidades e Tecnologias, 1749-024 Lisbon, Portugal \\ * Correspondence: leandro.pereira@iscte-iul.pt
}

check for updates

Citation: Pereira, L.; Pinto, M.; Costa R.L.d.; Dias, Á.; Gonçalves, R. The New SWOT for a Sustainable World. J. Open Innov. Technol. Mark. Complex. 2021, 7, 18. https://doi.org/10.3390/ joitmc7010018

Received: 22 November 2020

Accepted: 3 January 2021

Published: 6 January 2021

Publisher's Note: MDPI stays neutral with regard to jurisdictional clai$\mathrm{ms}$ in published maps and institutional affiliations.

Copyright: $\odot 2021$ by the authors. Licensee MDPI, Basel, Switzerland. This article is an open access article distributed under the terms and conditions of the Creative Commons Attribution (CC BY) license (https:// creativecommons.org/licenses/by/ $4.0 /)$.

\begin{abstract}
In today's complex and changing business environment the concern with sustainability has gained more notoriety. However, companies still do not have a sustainable perspective, but a shortterm one, where their values are constantly forgotten and this concept is no longer welcomed. This research demonstrates the need for companies to adapt and to start acting in this direction. Following a set of interviews conducted with professionals with management positions of high responsibility, findings reveal that although sustainability is on the management mind, strategies and tools need to be adapted to be at the core of the organization's strategic formulation. To support this process, a new SWOT analysis to fit a forward-looking sustainable world is proposed. Furthermore, due to the aggregative nature of the model, it represents an essential tool for an open innovation. "SWOT $i$ " integrates the concern with sustainability as one of its pillars, placing the values and impacts that each decision can have at the center of the strategic formulation, allowing their performance to leverage.
\end{abstract}

Keywords: sustainability; SWOT i; strategy; companies; values; performance; tools

\section{Introduction}

In the last few decades, we have been witnessing several changes in the business environment, which are increasingly complex and more competitive, thus making life more complicated for companies and their decision-making process. Therefore, how to plan and formulate strategies for enterprises plays a decisive role because the strategy is a pattern of objectives, purposes, and goals, and the main policies and plans to achieve them, expressed in a way that defines what business the company is or should be and the type of company it is or should be [1].

In recent times there have been major changes in the external environment of organizations and, as such, markets are no longer regulated by the same indicators as before, issues such as sustainability and environmental awareness have become extremely relevant to companies and as the environment changes, companies should no longer pursue profit maximization as their first goal but rather make efforts to practice sustainable management [2]. Due to its characteristics, sustainable management and sustainability are the basis for the reinvention of the companies.

According to the latest articles published on the subject of sustainability and sustainable management and also visible in the interviews conducted, the future of companies passes through here and those who cannot adapt will suffer the consequences in the short to medium term.

In this research, the SWOT (strengths, weaknesses, opportunities, and threats) analysis was taken as an object of study [3], because it is still today one of the most used tools by any company regardless of its size or industry where it operates and also because of its simplicity and clarity with which it is used [4]. Throughout the literature review, many criticisms have been made to SWOT analysis [5], however, no author identified a very serious gap that is not incorporating sustainability as one of its dimensions, nor integrating the values and impacts of each decision at the heart of its strategic formulation. 
Using a qualitative analysis approach based on in-depth interviews and data analysis by combining diverse tools (Word Frequency List, Word Cloud, and Word Association), this research aims to add value by showing the importance and relevance that the issue of sustainability can have within the business, developing a new adaptation of SWOT analysis, which can help companies develop new strategies capable of responding to new trends while maintaining competitiveness.

\section{Literature Review}

\subsection{Open Innovation}

Innovation is traditionally seen as a concept that occurs within a single company. However, several factors have contributed to the change in this thinking dynamic. The growing propensity for the mobility of thinking and knowledge-intensive employees, the emergence of the Internet and intelligent systems, the increasing complexity of risk capital markets, and cross-border supply to mitigate costs while generating differentiation effects are just a few examples that have called into question the effectiveness of today's traditional innovation systems, fundamentally SME (Small and Medium Enterprises) [6]. It was precisely under this assumption that the concept of open innovation emerged, the focus of which emphasizes the importance of the internal insertion of processes that are characterized by going beyond the boundaries of the company, not only ensuring its future in terms of strategic thinking with its own ideas, but also with ideas that result from external sources, which led to the analysis of open innovation in terms of literature being analyzed today from various perspectives, such as through studies on the industrial dynamics of open innovation [7], open innovation processes focused on certain industry sectors [8,9], or ways to foster open innovation within firms [10].

In this context, the literature on open innovation, especially from this century onwards, has grown considerably and various models have been created to describe its nature. Product and process innovation, radical innovation and incremental innovation, systemic innovation and component innovation, technological investment to attract new markets, or even more recently, closed innovation and open innovation. This panoply of visions has led to these models gaining different scope over the years, so there are linear models and chained models (these being more linked to the issue of innovation processes) but also models developed to suit developed countries and others developing countries.

In accordance with the multiple applicability strands of the concept of open innovation, we believe, however, that the applicability of the concept is strictly necessary in a strand covering the possible applicability of the concept where the nature of the innovation can be applicable to both large and small companies through the creation of own models that allow the creation of a more sustainable world. Contrary to the basic thinking of Vossen [11], and based on the assumption that open innovation must always be thought of from the perspective that it must always be created in different ways based on the difference between small and large companies, we prefer to focus on the assumptions of West et al. [12] and Maranto-Vargas and Gómez-Tagle Rangel [13], with the focus on the passage from a relatively closed world to a very open one that represents important challenges for companies as a whole.

This line of thinking also places the focus on building a network of thoughts that allows a greater robustness in the desired result. If we consider resource-based theory, this suggests that the decision on selection is based on the potential of partners to provide additional resources for mutual benefit [14]. We know, however, that for SMEs to seek out and decide with whom to collaborate to create an effective network can be difficult given their limited sources of information and lack of financial resources to collect vital information [15], compared to larger companies, which can for instance offer professional intelligence processes to scan and monitor their technological environments [10]. 
It is clear that SMEs have only been able to overcome this type of difficulty by building deep and lasting links when organizing themselves into a network [16], and it is crucial to create a collaborative network to work together more effectively to maximize their chances of innovation and increase the likelihood of success in developing new products and services fundamentally linked to sustainable means of future survival.

\subsection{SWOT Analysis}

\subsubsection{SWOT Definition}

SWOT analysis is one of the most widely used tools in the world because it allows a rapid and effective assessment of Strengths $(\mathrm{S})$, Weaknesses $(\mathrm{W})$, Opportunities $(\mathrm{O})$, and Threats $(\mathrm{T})$ faced by any organization or company regardless of the industry where it operates or its size [17].

Over the last few decades, many SWOT definitions have emerged that have contributed to building the image and relevance that this tool can have in managing a company. SWOT analysis allows an organization to have an integrated vision of its entire strategy, allowing one to find out how internal capabilities can relate to external capabilities to obtain competitive advantages and ensure the success of the company [4]. Over the years, many critics are attributed to SWOT analysis; however, this tool, for all its simplicity and applicability in any situation, continues (and will continue) to be one of the most used tools to formulate the strategy of any organization, as it is challenging to find other tools that can identify strengths and weaknesses and turn them into added value so effectively [5].

\subsubsection{Applicability, Use, and Purpose of SWO}

SWOT analysis is part of a set of tools that can be used to help plan and formulate strategies. Managers of organizations usually use these in the form of brainstorming and this has a priority to help to identify and position the capabilities and environment of the organization in each section of the tool and then make the right decisions $[18,19]$.

Due to the increasingly fierce competition, any organization must invest in its strategic planning process and must have the ability to create value where others cannot seize or see opportunities, neutralize threats, or mitigate their weaknesses [20]. However, for this to happen, it is essential to have the ability to build a unique strategy that would constitute a competitive advantage over its rivals. This can only happen by using tools such as SWOT that allow an integrated understanding of all dimensions of the company's internal and external environment to achieve levels of excellence [8]. For these reasons and for its ability to assist in the process of developing the strategy of a company, the SWOT analysis has been consistently used in many different businesses as a key tool $[3,5]$. Due to all of its features and associated benefits, this tool can be used in several contexts and areas such as business corporations, government departments, non-profit organizations, marketing development, reporting departments, and communication departments [21].

\subsubsection{Criticisms to SWOT Analysis}

As demonstrated, SWOT analysis continues to be one of the most used tools in any company's strategic process [3,5]. However, despite all this use and popularity, the traditional SWOT analysis has not been able to escape from several criticisms and objections regarding its methodology. Suffering from some analytical myopia, by not allowing it to analyze the company's internal environment in a correlative, comparative, and evolutionary way and, additionally, there is an evident lack of capacity to analyze in an open, heterogeneous, and differentiated way the opportunities and threats that occur in the external environment, which sometimes hinders companies' ability to adapt quickly and effectively to them [22].

Besides this, at times, the traditional SWOT analysis may not allow the most efficient evaluation of the internal and external environment because it is based on a qualitative analysis likely to hold subjective opinions and perspectives by the organization's administrators. In addition to this, it is evaluated only from the point of view of managers, not 
taking into account the perspective of customers, which is a mistake since they do not ensure that the capabilities of the organization are recognized and valued by them $[23,24]$.

This tool cannot substantially analyze a company's strategy as it offers unclear and ambiguous outputs, no differentiation or prioritization to the factors identified, no obligation to confirm the conclusions with any data or information, describing it as simplistic and superficial [19]. Still, no criticism is made that this tool does not give any importance to sustainability, climate change, and how it should be reinvented so that sustainability and the impact on people, society, and the planet from the SWOT tool's decisions are the center points and main feature of this tool. In increasingly competitive markets, and in the light of new perspectives and paradigms, profit is not the only objective, or this should be the result of doing the right things - the organization has shared interests with society and there are limits to economic growth, due to the need of preserving resources and ensuring their availability in the future [25]. The interest in sustainability is becoming increasingly important and relevant within the business and as such, any company must adapt its strategies and behaviors to incorporate this issue as a central dimension of the company's strategy to maintain competitiveness, but at the same time have a greater responsibility in terms of the impacts that their decisions may have on society, planet, and environment [26].

\subsection{Sustainability and Implications on SWOT Analysis}

2.3.1. Sustainable Development

Although there were conversations around sustainability by the end of the 19th century, by authors like Henry Thoreau (1854), Thorstein Veblen (1899), and William Morris (1891), the topic only gained worldwide proportions by 1987 with the benefit of the World Commission Report on Environment and Development (1987), also referred as the Brundtland Report [27]. Here, the possibility of a new economic growth era contemplated policies for a sustainable development that "sustain and expand the foundation of environmental resources" [28] (p. 13).

The Brundtland Report is where the commonly accepted definition of sustainability was presented as a development style with vision, recognizing the needs of current generations without compromising future ones [29].

Some years ago, topics such as sustainability, sustainable development, and Corporate Social Responsibility were not even a subject of conversation and concern. In recent years there has been an exponential interest from organizations in these issues, noting that they have gone from being marginalized concepts to being very relevant and necessary to be integrated into companies [30]. This sudden change is due to numerous factors, including uncertainty and the worsening state of the environment, as human behavior has caused a growing number of natural disasters [31]. Nowadays, organizations have to handle several risks associated with climate change, business globalization, scarcity of natural resources, increased market competitiveness, natural disasters, and unforeseeable financial crises by quickly reacting and changing their strategic models [32].

Records in the Sustainability Report describe how sustainable development is about long-term thinking and foresees the linkages between environmental effects, actions, and decision making [33]. Already in 1987, "The Brundtland Report", however not understating the need for economic activity, recognizes a needed shift in the path when it comes to reconciling the planet's ecological and natural resource boundaries with the required economic development. As a response to these issues, companies looked at sustainability as a resource and implemented initiatives and communicated them through sustainability reporting [34]. Sustainability Reporting is considered "public reports by companies to provide internal and external stakeholders with a picture of the corporate position and activities on economic, environmental and social dimensions" [35] (p. 8). 


\subsubsection{Corporate Sustainability}

Most authors in the area share the view that corporate sustainability requires companies to deal with economic, environmental, interconnected, and interdependent issues and social concerns at different levels. Furthermore, many of the literature studies on corporate sustainability used an instrumental logic where the economic dimension is prioritized over the other two dimensions beforehand [36,37].

Recent research focused on Industry 4.0 to highlight the sustainability importance [38-42], while other studies embraced a more specific approach establishing a direct relationship with the UN SDGs (Sustainable Development Goals) [43-49]. Other studies show that considering the direct effects of a company's actions on the environment and society and taking those into account leads to economic return, competitive advantage, and better performance [50-53]. Currently, companies' decision-making process under specific environment target markets has become more and more complicated to manage and fulfill. At the same time, investments are thought differently and analyzed according to other criteria, and it is no longer only the economic aspect that matters; it is also necessary to measure the impact they have in environmental and organizational terms, measure consumer satisfaction, and verify that the company's values are under decisions, among others, to make this whole decision-making process easier to follow, which is essential for the company to follow sustainable management practices that ensure that their outcomes meet what is intended [18].

In today's complex and continually changing environment, markets are no longer regulated by the same indicators as before. Issues such as sustainability and environmental awareness have become extremely relevant for companies in recent years, and as such, their implementation in company strategies has become a common goal within the same. For this to happen, it is necessary to develop new strategies that can respond to these trends and thus ensure organizations' competitiveness in the markets [54,55], as well new sustainable ventures [56,57]. We have seen major changes in the external environment of organizations in recent times. As such, they should no longer seek to prioritize the maximization of their profits at any cost but must steer towards sustainable management that provides decisions and measures that meet the expectations of consumers and leverage the image of the company. Since, for stakeholders, an organization's primary responsibility is to maximize the positive impacts of their decisions and minimize the negative, to draw and maintain them, companies must follow this path $[2,58]$.

\section{Methodology}

Research plays an essential role in developing knowledge of a discipline and, consequently, improving professional practice as a fundamental tool for scientific development and for describing and understanding social phenomena [59]. Research issues are central to the research strategy. As such, the objectives and the way the questions are asked condition the type of data to be collected and, in general, the kind of methodology to be adopted. By defining the research questions, it was possible to delimit the concepts to be studied, the data that relate to those concepts, and how it should be collected, so that the focus is more explicit and the objectives more easily achieved. Table 1 contains the research instruments and objectives supported by literature review.

Table 1. Research instrument and objective.

\begin{tabular}{llll}
\hline Literature Review Issue & \multicolumn{1}{c}{ Autor Reference (Date) } & \multicolumn{1}{c}{ Research Question } & \multicolumn{1}{c}{ Research Objective } \\
\hline $\begin{array}{l}\text { No concern with the } \\
\text { theme of Sustainability } \\
\text { in SWOT Analysis. }\end{array}$ & $\begin{array}{l}\text { Boonyarat Phadermrod (2019); } \\
\text { Richard M. Crowder (2019); } \\
\text { Gary B. Wills (2019) }\end{array}$ & $\begin{array}{l}\text { How sustainability is } \\
\text { integrated into } \\
\text { business strategy? }\end{array}$ & $\begin{array}{l}\text { Incorporate sustainability } \\
\text { concerns as a central } \\
\text { dimension of SWOT analysis } \\
\text { and increasingly present in } \\
\text { management decision making. }\end{array}$ \\
\hline
\end{tabular}


Table 1. Cont.

\begin{tabular}{|c|c|c|c|}
\hline Literature Review Issue & Autor Reference (Date) & Research Question & Research Objective \\
\hline $\begin{array}{l}\text { No understanding of the } \\
\text { need of evolution } \\
\text { of traditional } \\
\text { SWOT Analysis. }\end{array}$ & Charis M. Vlados (2019) & $\begin{array}{l}\text { Are the sustainable values of a } \\
\text { company relevant enough for } \\
\text { it to influence the decisions } \\
\text { taken? how the consequences } \\
\text { of a decision and the impact it } \\
\text { may have on society are } \\
\text { thought in advance to avoid } \\
\text { harmful business decisions? }\end{array}$ & $\begin{array}{l}\text { Put in the center of SWOT } \\
\text { analysis the values and the } \\
\text { impact that decisions have on } \\
\text { society so that these two } \\
\text { variables are present in the } \\
\text { decision-making of all } \\
\text { managers who use the tool. }\end{array}$ \\
\hline $\begin{array}{l}\text { Assessment focus on the } \\
\text { economic and profit side. } \\
\text { Values and impacts of } \\
\text { decisions are not taking } \\
\text { into account. }\end{array}$ & $\begin{array}{l}\text { Alex Coman (2009); Boaz } \\
\text { Ronen (2009) }\end{array}$ & $\begin{array}{l}\text { For what purpose is SWOT } \\
\text { used by the managers of a } \\
\text { company? It is only seen as a } \\
\text { useful tool for making } \\
\text { decisions that can generate } \\
\text { profit in any way, or it helps } \\
\text { companies to take into } \\
\text { account other concerns when } \\
\text { making decisions? }\end{array}$ & $\begin{array}{l}\text { Create a new version of SWOT } \\
\text { analysis that incorporates } \\
\text { sustainability concerns into all } \\
\text { decision making and that } \\
\text { subsequently allows for an } \\
\text { assessment of whether the } \\
\text { decisions that were made by } \\
\text { managers had these concerns } \\
\text { in mind and the impact that } \\
\text { these have in environmental, } \\
\text { social, and economic terms. }\end{array}$ \\
\hline
\end{tabular}

- $\quad$ SWOT analysis lacks accuracy and methodological completeness.

- Not portray the importance of incorporating the values in the center of the strategic formulation.
Marileide Barbosa (2020); Juan Arturo Castaneda-Ayarza (2020); Denise Helena Lombardo Ferreira (2020)
Nowadays almost all companies have values, which are related to environmental concerns, however, there is evidence that these values are being followed, and what management tool they use to achieve it?
Prove the need to create a management tool that is useful for managers to incorporate sustainability in all decision making.
- The relevance of climate change.

- The relevance of sustainability in the strategy of a company.
Duque et al., (2020)

Hanna-Leena Pesonen (2014);

Susanna Horn (2014)
Is sustainability relevant enough for a company to change its way of working, its procedures, and to be guided by a tool where sustainability is the center of everything?
Offer company managers a much more complete tool where sustainability is the support for all the decisions, which helps organizations to be better prepared to adapt and incorporate new strategies and that ensure the long-term success of the company.

This was chosen as a methodology for qualitative research that aimed to translate social realities through reports of experiences about the phenomena under study [59]. Selecting the method to collect the information is an essential aspect of the research process, one of the most used techniques to obtain data in qualitative studies is the interview [59]. This establishes a real exchange, during which the participant exposes his perceptions of an event or situation, his interpretations, or his experiences. After a thorough analysis of all existing research methods, the semi-structured interview was selected as a privileged information-gathering tool that allowed us to gather a huge and varied amount of information that would otherwise not be possible. These focused on the problem under study and followed a script of topics and questions coming from the theoretical framework so that all interviewees could express their opinions with freedom of both time and words. The interviews were completed with prominent personalities with great academic and practical knowledge of the research area. The interview scripts were made to obtain better 
knowledge about the relevance of sustainability for companies and understand how it is integrated into the company's strategy to deepen aspects related to the study object.

As far as interview participants are concerned, the sample represents the process of selecting the number of subjects participating in a study [60]. In general, the number of participants was small, as socially significant subjects were chosen because the concern as a researcher is to develop a rich and dense description of the phenomenon under study [61]. Due to the exploratory nature of this study, we followed a non-probabilistic purposive sampling. The obtained sample presented the following characteristics. 16 were male and nine were female. Regarding the years of experience, $8 \%$ had between 0 and 10 years, $48 \%$ between 10 and 20 years, $12 \%$ had between 20 and 30 years of experience and finally, $32 \%$ had between 30 and 40 years. We interviewed people who already had some years of experience, allowing us to contact professionals who had been involved in different contexts and situations and could add content and value to the research. Regarding the professional position, we classified the interviewees according to five different categories: President/Vice President, CEO/COO, General Manager, Sustainability Director, and Sustainability Specialist. It is possible to see from Figure 1 that about $48 \%$ of the interviewees held positions directly related to sustainability; however, the other $52 \%$ holding administrative and decision-making positions were also able to talk about any subject since they are the main ones responsible for any decision related to the company.

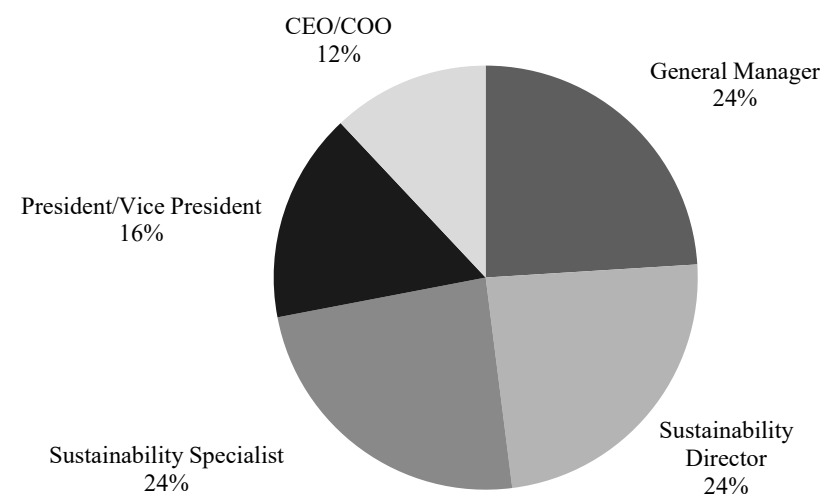

Figure 1. Sample description: professional position.

Finally, it is also important to mention the industry origin of the participants. As it is demonstrated in Figure 2, participants from different industries were interviewed, and thus it was possible to observe how sustainability and strategic planning are related in each one of them and the different decisions that are taken, according to the objectives defined for each one.

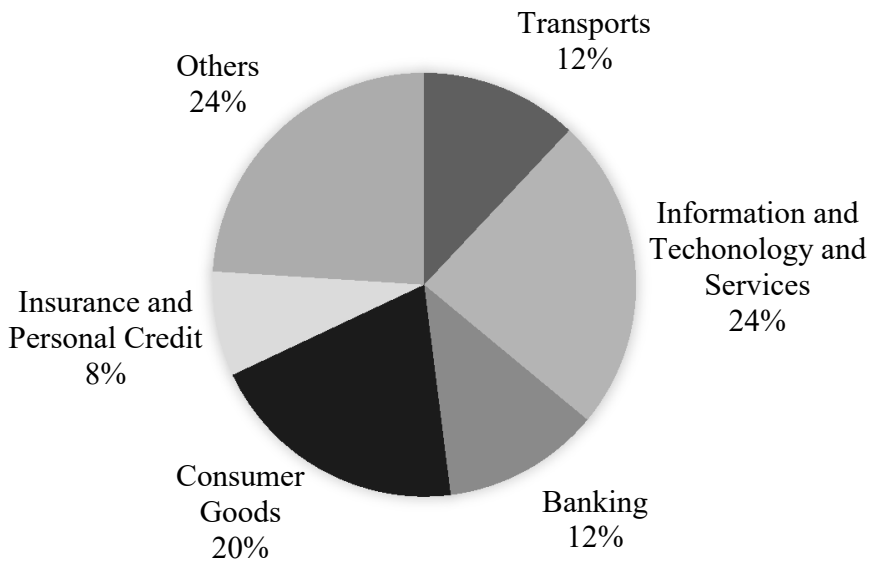

Figure 2. Sample description: industry distribution. 


\subsection{Variables}

The dependent and independent variables were selected among some that the literature considers essential and appear in various studies on sustainability and its importance for business management.

\subsubsection{Dependent Variable}

The dependent variable, also called the criterion variable or explained, is the one that suffers the effect of the independent variable [59]. The weight that sustainability has in the company's strategy was then defined for this study as a dependent variable.

\subsubsection{Independent Variable}

The independent or experimental variable is the one that the researcher manipulates in the study and is considered the cause of the dependent variable [59]. These variables were divided into three groups: (1) Variables of the Organizational Environment: Size of the company; Industry in which it operates; Position that the interviewee occupies in the company; (2) Variables of Sustainability Relevance: The relevance of sustainability for the company; Motivations to become Sustainable; Sustainability issues, Existence of sustainable behaviors; Disadvantages and difficulties to adopt sustainable behaviors; (3) Strategy Characterization Variables: Agenda 2030; Sustainability as a business opportunity; Sustainability as an obligation; Sustainability goals; Tools used to formulate strategies; Sustainable tools available. All the variables included in this research project are related and directed to two related concepts: sustainability and strategy formulation, which will be explained later. These must be able to be measured, which implies that they are operational [59].

The final interview script is detailed in Appendix A.

\subsection{Data Collection}

After a thorough analysis of all existing research methods, the semi-structured interview was selected as a privileged information-gathering tool that allowed us to gather a huge and varied amount of information that would otherwise not be possible. These focused on the problem under study and following a script of topics and questions coming from the theoretical framework so that all interviewees could express their opinions with freedom of time and words. The interview script was validated by three professionals with strong academic and practical knowledge of the research area. The interview scripts were made to obtain better knowledge about the relevance of sustainability for companies and understand how it is integrated into the company's strategy to deepen aspects related to the study object.

All the interviews, which we designated as exploratory, were conducted online due to the pandemic situation and were undertaken by one of the researchers. The objectives and the scope of the research were clarified to the interviewees, and consent was obtained to participate in the study and to record the interviews. Interviews took place between May and August 2020 and were recorded, in audio support, for later transcription and content analysis. They had an average duration of $30 \mathrm{~min}$ and were transcribed chronologically, in Word document format, with fidelity to the speech.

\section{Data Analysis}

The first tools used to analyze the content of the interviews were the Word Frequency List and the Word Cloud allowing us to visualize the words that were most frequent during the interviews and thus draw some relevant conclusions. As previously mentioned, text mining was conducted as a form of qualitative analysis, to obtain from all interviews the most relevant information to be analyzed and discussed as stated by Goswami and Shishodia [62].

The second method used in text mining was Word Association. This qualitative methodology is widely used in specific research areas and investigations such as psychology and sociology $[63,64]$. This methodology is based on inferring which words are most 
often associated with each other to understand the concepts and themes most relevant to the interviewees that should be studied $[64,65]$. In total, four of the most debated words and concepts during the interviews were chosen as objects of analysis.

The research's main goal fell on a group of interviews with Portuguese professionals that got themselves in a position of leadership or management. After an intensive method of analysis, the choice was emphasized on a privileged focused problem guided by many questions and topics under the logic of interviews that could express the point of view of those with experience, with complete freedom.

Before choosing the personalities, research about their backgrounds was made, and the selection was guided to a path of professionals with an academic background and practical knowledge, a symbiosis that culminates in a powerful connection to this research project. The most significant knowledge that those individuals bring to this work has no similarity to another type of connection that we can fulfill in a pandemic time of few physical movements and fewer meetings. That is why this knowledge leads us to the relevance of sustainability in companies and their strategies to understand the purpose of deepening aspects connected to our object of study [66].

The sample that was collected represents the principal concern of representation of a process determined by selecting the number of subjects participating in this study. The number of 25 was reached by the pretensions of what we want to do, dealing with practical and theoretical knowledge in those areas of interest. Directors and managers of organizations are the main attraction since they are the actors inserted at the core who can provide the knowledge and detailed information on management's used process to fulfill organizational objectives better.

\subsection{Text Mining}

From the 25 conducted interviews, it was possible to obtain relevant information that allowed identifying and analyzing the differences and similarities between the interviewees' opinions, and that is very important to conclude [67]. Several tools were used to analyze the data, and the most important topics under research were organized according to the different categories on which the text mining was done, demonstrated on the following pages. Subsequently, all the qualitative results gathered from this detailed analysis must be appropriately compared to the literature and emerging theory to reach valid conclusions [68].

\subsubsection{Word Frequency}

The first tools used to analyze the content of the interviews were the Word Frequency List and the Word Cloud allowing to visualize the words that were most frequent during the interviews and thus draw some relevant conclusions. Figures 3 and 4 shows the results for the word frequency analysis.

It can be observed that the word most commonly used was sustainability. This comes as no surprise due to the topic of the interviews but also, from a historical perspective, sustainability has always been a key theme in many discussions on various issues, however, it has increasingly gained notoriety and recognition from the business world that increasingly sees this topic as an opportunity to evolve and ensure long-term success [25,66]. The particular position sustained by the generality of the interviewees, when questioned about the relevance of sustainability was to demonstrate the importance that this subject has for the organization and that this has to be considered as a fundamental theme in the strategy of the company, at the same time it should be one of the main values to be followed by them, being in line with the ideas of Cochran [30] when he stated that the issue of sustainability for organizations has undergone a major change in the way it is viewed, moving from a marginalized issue to something completely central to the success of any company's strategy. On the other hand, when questioned about certain behaviors and evidence, sometimes it does not correspond to the discourse that it has prepared, and sustainability is not integrated into the company's strategy as it should be. 


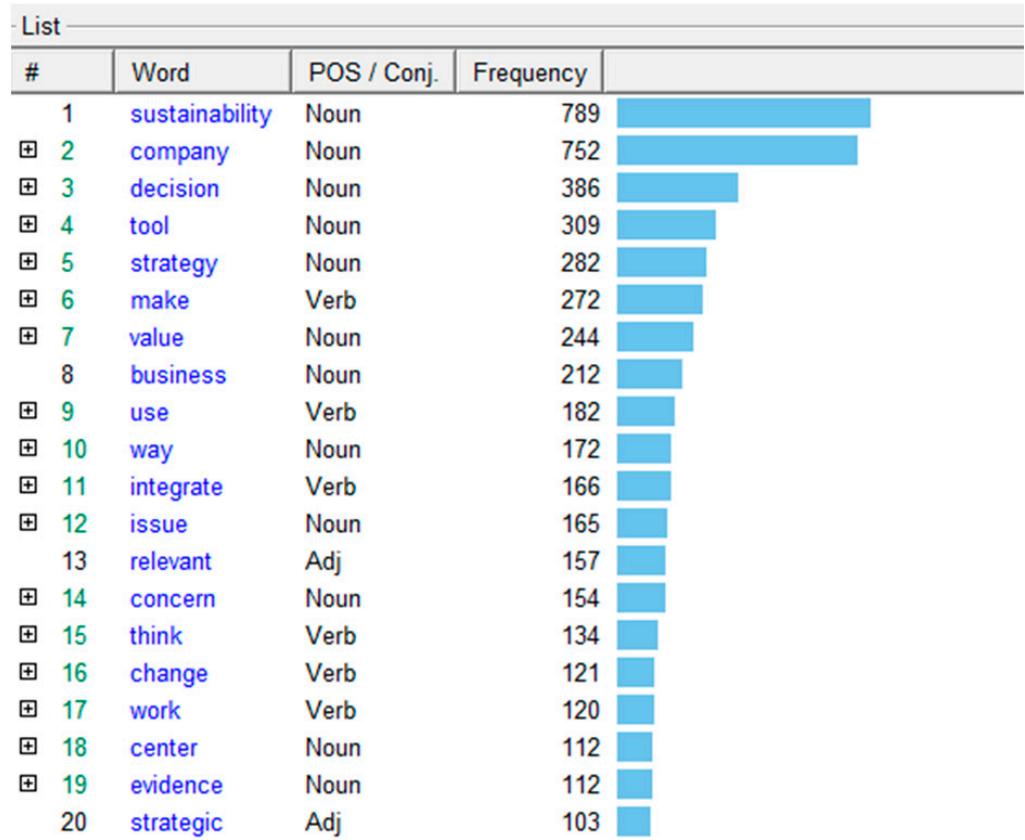

Figure 3. Word frequency list.

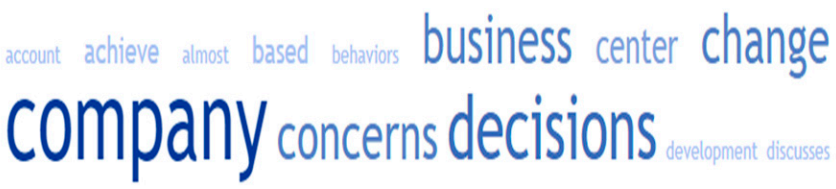

enough environmental everything evidence followed generate guided helps impact

important incorporate integrated issue main making

management market modal objectives opportunity procedures products profit

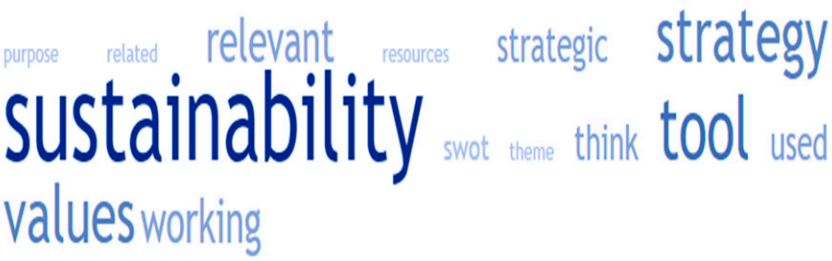

Figure 4. Word cloud.

When analyzing the images described above, other words deserve to be targets of analysis. One of these is strategy, the interviewees defined it as something central to achieve the objectives that were previously defined, however it was mentioned several times that this is influenced by the tools that the company has at its disposal and that directly influence the decisions that are taken by the company, agreeing with the definition of strategy as a set of objectives, purposes, and goals to be achieved from a set of decisions that are taken with the help of certain tools [1]. Going a little further, some interviewees complain about the lack of tools that end up helping to integrate the issue of sustainability into the company's strategy, stating that most decisions are not taken in this sense because the company does not have at its disposal the means to do so, sometimes through its own fault and because sustainability is still seen as an obligation and not an opportunity, other times because no tool incorporates sustainability at the heart of all decisions, and this proves that in today's complex and changing business environment in which companies operates it is necessary to carefully develop strategies that promote sustainability as a 
central theme and not as an obligation, in order to gain a competitive advantage in the long term and to remain competitive [25]. There are also other words widely used by the interviewees and which will also be the subject of analysis at a later stage, one of these cases is the values and how these are esteemed, the way they are integrated and used in the company's strategy and whether they are really followed, and there is evidence of this, or whether on the other hand they are forgotten and put aside to the detriment of the opportunities that arise in the market. The values must be present in any company's decision-making process, and when they are followed, they have only to gain by having the ability to increase the existing trust between customers and the company [69].

Simultaneously, other keywords such as SWOT analysis have great importance in these interviews' content and must be analyzed in detail, considering their relationship with other frequently used words. As it was inferred from the interviews, this is still one of the most used tools by any company's management, however, people have not realized the correct way to work with it [70].

Many of the interviewees when questioned about the way sustainability was integrated into the company's strategy, divided the concept into three different strands: an economic one where they mentioned the importance that adopting sustainable behaviors can have for the company's financial health in the medium and long term, another one is the social, where depending on the interviewee's industry, they developed several behaviors to support the local community and social responsibility, and finally, the third one is environmental, where they listed several pieces of evidence of behaviors such as reducing GHG emissions, reusing raw materials, recycling, reducing the use of plastic, among others. All of these responses show that the success of companies in the future would depend on their ability to meet financial, social, and environmental needs, also known as the Triple Bottom Line, and later considered to be one of the best ways to integrate sustainability into business strategies and leverage them for the future [54,71].

Another of the themes often mentioned during the interviews were the values, where most of the interviewees, when questioned, defined them as guidelines for the company's behaviors in the market and influenced its strategies, yet some of the interviewees stated that that values are often set aside when there are sometimes more financially advantageous options for the company, and this situation is also influenced by the size and industry in which the company operates. This proves Bora et al. [72] theses regarding the large number of researches that were conducted in the area of management and strategy, however little was studied about the importance that values, mission, and vision of a company can have, to achieve the strategic objectives of a company, feeling that these are still put aside when it is necessary.

Finally, it is also worth mentioning another three words that stand out in this cloud of words. One of them is opportunity-for most of the interviewees, this is a keyword that demonstrates how sustainability should be faced. It is easy to realize that for many of the respondents, this is still a concept seen as an obligation and not as an opportunity and this mentality has to change quickly [34]. The other two words are relevance and evidencemany of the answers obtained addressed the importance and relevance that sustainability has for the company, responding that this is a very important issue in the strategy and that there are concrete measures that prove it. However, when we look for evidence, in some cases, this does not happen, which shows that there is still a great difficulty for companies to choose the path of sustainability over the easier path that is to try to make a profit at any cost, without thinking about the future of the company in the long term [73].

\subsubsection{Words Association}

The second method used in text mining was Word Association. This qualitative methodology is widely used in specific research areas and investigations such as psychology and sociology $[63,64]$. This methodology is based on inferring which words are most often associated with each other to understand the concepts and themes most relevant to 
the interviewees that should be studied [64]. In total, four of the most debated words and concepts during the interviews were chosen as objects of analysis.

The first word to be analyzed was the strategy. Figure 5 show the word association for Strategy.

\begin{tabular}{|c|c|c|c|c|}
\hline \multicolumn{2}{|l|}{ \#direct } & \multicolumn{2}{|c|}{ Coding Rule File: Browse } & No File \\
\hline & & \multirow{2}{*}{\multicolumn{3}{|c|}{$\begin{array}{l}\text { \#direct: and }-|| \text { strategy } \\
\text { AND }-\mid \text { Unit: Paragraphs }\end{array}$}} \\
\hline & & & & \\
\hline \multicolumn{5}{|l|}{ Result: } \\
\hline \begin{tabular}{l|l}
$\mathrm{N}$ & word \\
\end{tabular} & POS & unconditional & conditional & Jaccard \\
\hline 1 integrate & Verb & $166(0.046)$ & $148(0.525)$ & 0.4933 \\
\hline 2 business & Noun & $212(0.059)$ & $102(0.362)$ & 0.2602 \\
\hline 3 sustainability & Noun & $737(0.204)$ & $111(0.394)$ & 0.1222 \\
\hline 4 change & Noun & $53(0.015)$ & $32(0.113)$ & 0.1056 \\
\hline 5 company & Noun & $726(0.201)$ & $89(0.316)$ & 0.0968 \\
\hline 6 result & Verb & $25(0.007)$ & $25(0.089)$ & 0.0887 \\
\hline 7 main & Adj & $66(0.018)$ & $28(0.099)$ & 0.0875 \\
\hline 8 behavior & Noun & $56(0.015)$ & $27(0.096)$ & 0.0868 \\
\hline 9 discuss & Verb & $32(0.009)$ & $25(0.089)$ & 0.0865 \\
\hline 10 ritual & Noun & $25(0.007)$ & $24(0.085)$ & 0.0848 \\
\hline
\end{tabular}

Figure 5. Strategy word association.

It was practically universal for all the interviewees that strategy is an indispensable mean to reach the expected results and objectives and, in this way, to guarantee a good functioning of their companies in obtaining a competitive advantage in their business environment. This proves what Michael Porter stated many years ago, that any company that wants to reach success has to have a well-structured and defined strategy in three basic pillars in order to create a competitive advantage over its competitors [74]. So, it is easy to understand why words such as business, company, results, and behaviors are well associated with strategy. Besides this, the word sustainability and integrate were among the most associated with strategy and this means something because more managers and directors of companies are realizing that it is inevitable to choose the path of sustainability and that it is necessary to change the way of thinking and acting on the market, for this sustainability must be integrated as a fundamental theme in the strategy of any company. Like Chung et al. [25] mentioned, companies that do not realize this quickly will end up suffering the consequences of their decisions because the market is increasingly complex and volatile, resources are becoming scarce, competition is increasing, and as such, it is necessary to change the capitalist mindset to generate profit at all costs, even if compromising the future of the company in the long term and begin to choose other paths.

The second word analyzed was sustainability. Figure 6 show the word association for Sustainability. 


\begin{tabular}{|c|c|c|c|c|}
\hline \multicolumn{2}{|l|}{ \#direct } & \multicolumn{3}{|c|}{ Coding Rule File: Browse No File S } \\
\hline & & \multicolumn{3}{|c|}{ \#direct: and $=$ sustainability } \\
\hline & & AND -1 & Unit: Par & ragraphs - \\
\hline \multicolumn{5}{|l|}{ Result: } \\
\hline \begin{tabular}{l|l}
$\mathrm{N}$ & word \\
\end{tabular} & POS & unconditional & conditional & Jaccard \\
\hline 1 company & Noun & $726(0.201)$ & $221(0.300)$ & 0.1779 \\
\hline 2 strategy & Noun & $282(0.078)$ & $111(0.151)$ & 0.1222 \\
\hline 3 relevant & Adj & $156(0.043)$ & $94(0.128)$ & 0.1176 \\
\hline 4 integrate & Verb & $166(0.046)$ & $89(0.121)$ & 0.1093 \\
\hline 5 issue & Noun & $164(0.045)$ & $85(0.115)$ & 0.1042 \\
\hline 6 center & Noun & $112(0.031)$ & $60(0.081)$ & 0.0760 \\
\hline 7 business & Noun & $212(0.059)$ & $60(0.081)$ & 0.0675 \\
\hline 8 guide & Verb & $88(0.024)$ & $49(0.066)$ & 0.0631 \\
\hline 9 central & Adj & $41(0.011)$ & $35(0.047)$ & 0.0471 \\
\hline 10 procedure & Noun & $75(0.021)$ & $34(0.046)$ & 0.0437 \\
\hline
\end{tabular}

Figure 6. Sustainability word association.

In this table, we address the theme of sustainability and its relationship and association with other words. Looking at the table, it is easy to conclude that the associated words are similar to the previous one. According to most of the interviewees, there is no escape, and it is necessary to understand that sustainability and company are two words that have to be connected and where the second cannot exist without integrating the first. It is possible to visualize in the table that the second and third words most associated with sustainability are "strategy" and "relevant" and this happens because they are directly related to the topic and this is demonstrated in some of the questions asked during the interview. In the first place, it was asked if sustainability is a relevant issue for the companies to which the interviewees belonged, and most of them answered yes. However, when asked how it was integrated into the company's strategy, the answers varied. Some stated that a sustainability department was created to integrate the issue into the company's strategy, others affirmed that the issue has always been part of the company's daily routine, which is not later proven in their behavior. Further, others stated that they have no specific measures to do so and that they adopt isolated behaviors in this sense, using the business model and the industry where the company is inserted as an excuse. At the same time, all those interviewed recognized the importance that the issue of corporate sustainability may have for the future of companies and that despite being a concept somewhat exploited by most companies there is much space to grow and work in this direction. This is in line with what was written by some authors such as Dangelico et al., Hoffmann et al., Lloret, and Reuter et al. $[50,51,53,75]$, where they explain that organizations that look at the issue of corporate sustainability with responsibility and take into account the impacts that their actions may have on the environment, planet and society, will naturally achieve an economic return, competitive advantage, and better performance.

The third word analyzed was value. Figure 7 show the word association for Value. 


\begin{tabular}{|c|c|c|c|c|}
\hline \multicolumn{2}{|l|}{ \#direct } & \multicolumn{3}{|c|}{ Coding Rule File: Browse No File Se } \\
\hline & & \multicolumn{3}{|c|}{ \#direct: and $\sqcup$ value } \\
\hline & & AND - & \multicolumn{2}{|c|}{ Paragraphs } \\
\hline \multicolumn{5}{|l|}{ Result: } \\
\hline $\mathrm{N}$ word & POS & unconditional & conditional & Jaccard \\
\hline 1 nowadays & Adv & $52(0.014)$ & $51(0.198)$ & 0.1977 \\
\hline 2 company & Noun & $726(0.201)$ & $113(0.440)$ & 0.1299 \\
\hline 3 decision & Noun & $385(0.107)$ & $59(0.230)$ & 0.1012 \\
\hline 4 base & Verb & $75(0.021)$ & $30(0.117)$ & 0.0993 \\
\hline 5 follow & Verb & $76(0.021)$ & $29(0.113)$ & 0.0954 \\
\hline 6 level & Noun & $39(0.011)$ & $25(0.097)$ & 0.0923 \\
\hline 7 actually & Adv & $51(0.014)$ & $25(0.097)$ & 0.0883 \\
\hline 8 relate & Verb & $61(0.017)$ & $25(0.097)$ & 0.0853 \\
\hline 9 environmental & Adj & $85(0.024)$ & $26(0.101)$ & 0.0823 \\
\hline 10 strategic & Adj & $103(0.028)$ & $26(0.101)$ & 0.0778 \\
\hline
\end{tabular}

Figure 7. Value word association.

The particular position sustained by most interviewees when questioned about the values relates them to environmental concerns and guidelines that guide the strategic decisions taken. For some of them, these values have a shelf life of 2 to 3 years and must be adapted according to the characteristics of the environment, hence words such as nowadays are quite associated with it. The main question made to the interviewees about values was that when a company has to take strategic decisions, what is taken into consideration first: is it the values of the company or do they take at any cost the opportunities of the market, even if it goes against the values. The answers were divided, although everyone agreed that these are very important and should always be followed, many said that they would not be true if they stated that this happens; often these values are ignored, whether by what the market requires or by choice of the company and their behaviors reflect this. However, there is a willingness from the interviewees to change this mentality. One of the interviewees mentioned the fact that the size of companies influences this type of behavior, and in a multinational where management differs from country to country, it is sometimes more difficult to universalize values and follow them in all decisions. In turn, another interviewee said that the behaviors and values of the company are the reflections of its employees and as such this is a very important factor to take into account in the recruitment phase of any employee. Another of the interviewees said that although the values are quite important, we cannot be naïve and not admit that sometimes the market and the external factors influence the decisions that the companies take, so it is impossible to follow $100 \%$ the values of the company, for him, a balance must exist between the two. According to Beerman [32], if a company has a certain mission, vision, and values, it should try to follow them and not adjust to the circumstances of the environment, what should change is the execution of the company's strategy in the face of changing the environment's circumstances, but always maintaining and taking into account their values, vision, and mission, being a little far from what is done by most of the interviewee's companies.

The fourth word analyzed was SWOT. Figure 8 show the word association for SWOT. 


\begin{tabular}{|c|c|c|c|c|}
\hline \multicolumn{2}{|l|}{ \#direct } & \multicolumn{3}{|c|}{ Coding Rule File: Browse No File } \\
\hline & & \multicolumn{3}{|c|}{ \#direct: and $-\sqrt{\text { swot }}$} \\
\hline & & AND - & \multicolumn{2}{|c|}{ Paragraphs } \\
\hline \multicolumn{5}{|l|}{ Result: } \\
\hline $\mathrm{N}$ word & POS & unconditional & conditional & Jaccard \\
\hline 1 manager & Noun & $60(0.017)$ & $42(0.553)$ & 0.4468 \\
\hline 2 model & Noun & $65(0.018)$ & $36(0.474)$ & 0.3429 \\
\hline 3 purpose & Noun & $58(0.016)$ & $34(0.447)$ & 0.3400 \\
\hline 4 rq-for & Adj & $25(0.007)$ & $25(0.329)$ & 0.3289 \\
\hline 5 use & Verb & $180(0.050)$ & $58(0.763)$ & 0.2929 \\
\hline 6 analysis & Noun & $46(0.013)$ & $21(0.276)$ & 0.2079 \\
\hline 7 useful & Adj & $52(0.014)$ & $16(0.211)$ & 0.1429 \\
\hline 8 concetual & Adj & $10(0.003)$ & $9(0.118)$ & 0.1169 \\
\hline 9 formulate & Verb & $28(0.008)$ & $9(0.118)$ & 0.0947 \\
\hline 10 tool & Noun & $309(0.085)$ & $24(0.316)$ & 0.0665 \\
\hline
\end{tabular}

Figure 8. SWOT word association.

In this last table and being SWOT, an analytical analysis tool, it is easy to understand why words like analysis, manager, model, and tool are the most used together with it during the interviews. This appears as one of the most used words, concluding through the interviews that it is still today one of the most used tools of analysis in the process of formulating a strategy by the managers of a company. For the interviewees, this happens due to its simplicity, ease of use, clarity, and it can analyze any context and situation, such as competitors, opportunities, and threats, among other situations. Through the analysis of the interviews, it was possible to realize that for many companies with little investment capacity, such as micro and medium enterprises, tools such as SWOT become indispensable to create their strategies. However, many of these respondents also admit that SWOT has its flaws and should be complemented with the use of other tools to make the best decisions [5]. For the majority of the interviewees, the pandemic has exposed the need for companies to reformulate and change their strategies. Issues such as sustainability must be integrated into the core of these strategies and tools, because if this does not happen many organizations will not survive. Tools such as SWOT, for their ease of use and accessibility, can be an opportunity and salvation for them, allowing them to change their mindset and way of acting without having to invest a large amount, but for this to happen SWOT also needs a major reformulation. This reaffirms what Hill and Westbrook [19] said in the past, that due to all the flaws and criticism to which SWOT was subjected it was time to stop and reformulate it.

\subsubsection{Bigrams and Trigrams:}

One of the most used text mining techniques is bigrams and trigrams. This happens because multi-word features can provide information that is sometimes more relevant and efficient to obtain objective conclusions than analyze single words that are isolated and often challenging to understand the context [76]. When analyzing a bigram or trigram, it is normal to find phrases with articles or pronouns in the most frequent ones, however, in this data analysis in the case of bigrams, these stop words were excluded to analyze the 
ones with more relevance. Figures 9 and 10 shows the resulting bigrams and trigrams for this research.

\begin{tabular}{|l|r|}
\hline N-Gram & Frequency \\
\hline Sustainability is & 221 \\
\hline integrated into & 129 \\
\hline making decisions & 105 \\
\hline business strategy & 102 \\
\hline relevant enough & 100 \\
\hline
\end{tabular}

Figure 9. Bigrams.

\begin{tabular}{|l|r|}
\hline N-Gram & Frequency \\
\hline the center of & 109 \\
\hline is integrated into & 104 \\
\hline sustainability is integrated & 103 \\
\hline integrated into business & 101 \\
\hline into business strategy & 101 \\
\hline
\end{tabular}

Figure 10. Trigrams.

At first glance, it is observed that the most used bigram during the interviews was "sustainability is". It was perceptible that the concept has different definitions for each one of the interviewees. Sustainability is a confusing concept where there is a set of definitions and opinions about it [77]. By analyzing the interviews it is possible to realize that the concept of sustainability is very broad-for some it is seen as an obligation and they comply with certain measures because it is necessary to operate in the market, for others sustainability is the only way forward and if it did not exist their companies would not exist either. In some cases it is seen as an opportunity to expand their services and products, and there are also other situations where they consider that sustainability is a very important concept for the future of all companies and that it can play a very important role in three fundamental areas of any company - the economic, social, and environmental parts. All the bigrams and trigrams identified in the table are somehow connected, if the former bigram leads us to understand the variety of definitions that sustainability creates, it is also necessary to understand the others. As one of the main objectives of the interview is to understand the relevance of sustainability in companies and how it is integrated into their strategies, it is normal that bigrams and trigrams such as "relevant enough", "integrated into", "making decisions", "into business strategy", and "the center of" are quite pronounced. However, it is important to analyze and understand that they demonstrate what is intended to be discovered, that is, the relevance of the topic for the company, the business strategy used, how sustainability is integrated into it, and the decisions made in this sense. By looking at the interviews in a generalized way, it is possible to infer that 
the subject of sustainability has been gaining more relevance, however, if we translate it into strategic terms, there is still very little evidence of sustainable practices on the part of organizations. This is much to the fault of those who run the companies but also due to an evident lack of tools that integrate sustainability as a major dimension of any strategy, to make sustainable decisions that create evidence that the subject is taken into account and important for the company.

\subsubsection{Text Correlation and Mind-Mapping}

The correlation of words is of great importance in text analysis such as text retrieval, keywords extraction, and text clustering, among others [78]. Text correlation is a highprofile task in different fields that allows us to preserve specific patterns and relationships between words that lead us to draw important conclusions from the text under analysis [78].

According to Biggs and Ramsden $[79,80]$ the mapping techniques made it possible to illustrate the information analyzed in the form of figures and diagrams, enabling a much easier understanding of the relationship between all the themes, contributing to a more effective and conclusive analysis by the researchers. In agreement, Davies [81] affirmed that more students, researchers, and analysts have used software mapping tools as an analytical methodology in recent years. These are used to allow detailed analysis of concepts and the various relationships between them, using diagrammatic relationships rather than written or verbal methods, to provide a clearer way to illustrate the understanding of complex topics.

When looking at the mind map in Figure 11, it is possible to see that it is divided into subgraphs of words with different frequencies. Starting by analyzing subgraph 08 , it consists of three words that are undoubtedly connected and interlinked. In the case of a business organization, these face highly diverse risks that they have to recognize, reflect on, and handle. For Loebbecke and Wareham [82], recently, business decision making under the uncertain external environment of markets becomes more complicated than before, and for a company to be able to face this, it is indispensable to have a business strategy that allows it to analyze the various aspects, not only financial but also organizational, adding the customer satisfaction to achieve the defined objectives. Thus, these authors confirm what was possible to take from the interviewees, and that is demonstrated in the mind map-any company needs to have a well-developed and planned strategy, if this does not happen, it will not achieve its objectives.

Concerning subgraph 07 , one of the main pieces of information to retain from the interviews is that the word management is significantly associated with the concept of strategic management, this is related to all the management processes of the company since the choice of vision, mission, objectives, analysis of the external and internal environment, and implementation of the strategy [83]. Simultaneously, the management concept is linked to other words like "follow", "actually", and "achieve."

In turn, subgraph 06 is linked to subgraph 02 . In regards to 06 , it started by analyzing the word tool that was one of the most frequently used during the interviews. One of the conclusions drawn from this mind map is that the interviewees often use tools to plan the company's strategy. When asked what tools they used in their daily tasks, the answer suggested that most of the time, not only one is used, but several that eventually complement each other and allow better planning. One of the questions asked was if there was a need to create tools to incorporate sustainability into the core of all decisions to facilitate all companies' lives. The answer was unanimous, and everyone said yes, demonstrating a clear gap in this field, which may be one reason why companies do not integrate sustainable perspectives into their strategies. This reaffirms what was said by Chung et al. [25], when they mentioned that companies have to find new ways to adapt and develop their strategy, seeking other alternatives to remain competitive. About subgraph 02 , it contains a word that was widely used by the interviewees, and that remains today as the main objective of all companies, which is "profit". Besides this, words such as "decision", "generate", and "make" are part of it that makes sense because to generate 
profit is necessary to make decisions that are useful to achieve this objective. Nevertheless, another word highlighted was "help", which demonstrates the need that some interviewees expressed to find a tool that allows reconciling the issue of sustainability with the constant obsession to make a profit at any cost and that demonstrates that if companies choose the path of sustainability, good financial results are something that will appear naturally. As the subgraphs indicate, this is the right "way" to achieve long-term success, reaffirming what Robbins [2] stated that companies should not pursue profit maximization as their primary goal and that efforts should be made to change the mindset of managers and administrators to realize that other goals, such as minimizing the impact of decisions on society and environment, enhancing the corporate image, and practicing sustainable management are even more important.

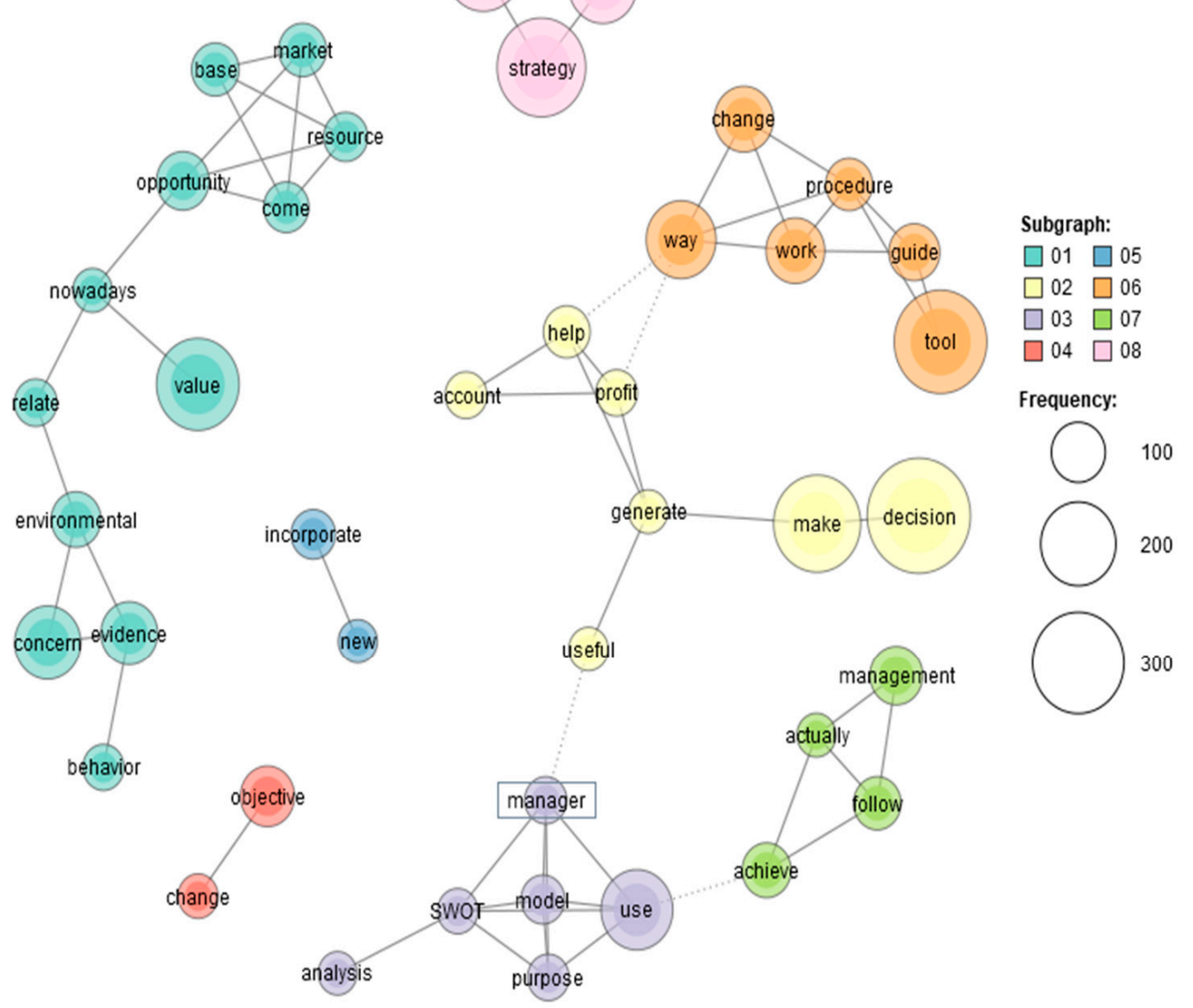

Figure 11. Text correlation and mind mapping.

As far as subgraph 03 of the mind map is concerned, it allows us to address one of the most talked about topics during the interviews: the SWOT analysis. For part of the sample, this is still a very useful tool used in several situations, yet many interviewees consider that SWOT analysis needs a reformulation to adapt to what the market today asks and needs [19]. It is also important to mention that it is possible to visualize in the mind map that this subgraph 03 is also linked to 07 and 02 from the words "useful" and "achieve", demonstrating the value that this tool can have for the company to achieve its goals.

Subgraph 05 includes the words "integrate" and "new". Through the reading of the interviews and successive analysis, it becomes visible that these two words are directly associated with the need that the interviewees referred to create new tools that put sustainability as the central dimension of them and that allow them to measure the impact that their decisions have on society, the planet, and the environment. This involves adopting a 
perspective of sustainable management that goes according to what Constanza [84] said when he mentioned that companies must have the ability to meet their needs without compromising the welfare of subsequent generations.

Looking at subgraph 04 , it is composed of the relationship between two words: "objective" and "change". One of the interview questions was related to the company's future objectives, mainly in sustainable terms. The word "change" has a strong link with "objective" because it is mandatory to change the companies' strategies if they want to remain competitive in the long term and thus achieve the objectives they have set themselves. There is already some evidence of these changes, such as changing the company's fleet to be electric, changing installations, changing production methods, changing the type of services and products, among many others, but is still too little to demonstrate that companies are changing and starting to look at the issue of sustainability with other eyes. Robins [58] has affirmed that more stakeholders (consumers, shareholders, employees, communities, suppliers, and governments) believe that organizations must maximize the positive impacts on the environment and society and minimize the negative ones, for this to happen, it is imperative that companies change their way of thinking and acting.

Finally, in subgraph 01, several concepts were discussed during the interviews and were related to each other. One of these links happened between the word "behavior" and "evidence". During the interviews, all the interviewees, when questioned about the relevance of sustainability for the company, answered that it was vital, then when asked if their behaviors reflected this, most of them answered yes. However when asked for evidence of these same behaviors, in some cases what was said did not correspond well to the truth, demonstrating that it is necessary to act in this sense and change and quickly, because in the medium-short-term the companies that do not will suffer the consequences of this. Moreover, when questioned about what sustainability is for them, most managers' particular position is to divide the issue into three strands-the environmental, economic, and social, agreeing with what Elkington [54] said with the concept of the Triple Bottom Line. Finally, it is important to mention that the interviewees assume that although sustainability is often an obligation for the company, it should be seen as an opportunity, as mentioned in the mind map. As Cuevas [31] referred, many factors have helped to enhance sustainability, and this growing concern, with the subject, yet, although there is a greater mobilization to make the issue part of the agenda of the organizations' strategy, there are still no significant changes that accompany the importance that the issue has to ensure success in the future of companies. At the same time, consumers are more and better informed, more responsible in choosing their products and services, and the scarcity of resources and climate change are a big warning that things need to change. Moreover, there is a perfect notion that without meeting certain sustainability criteria, companies will have no future.

\subsubsection{Text Clustering}

Text clustering is one of the most important texts mining techniques. Clustering of the text plays a vital role in efficient document organization, summarization, topic extraction, and information retrieval [78].

One of the topics discussed during the interviews was the role of values in a company. The particular position sustained by most managers, when questioned about the role of values, tends to associate them with environmental and sustainable concerns. For these, the values also have a lifetime and as such should be changed according to market trends. This data analysis also showed us that the greater the importance and relevance of the issue of sustainability for the company, the greater would be the attention given to values, much to the fact of sustainability being one of the main values of companies today. In these cases, it is mandatory that they are followed $100 \%$ because the business depends very much on the same [85].

Therefore, and as it is possible to see in the figures, the values are very much associated with the theme of sustainability and sustainable practices and their behaviors. The word 
"sustainability", which can be found in the pink branches of Figure 5, is linked to other words such as "relevance", "company", "change", "integrate", "center", "important", "behavior", "impact", and "obligation", among others. All these relations demonstrate what was said by the interviewees, that is, the theme of sustainability is something relevant for companies, yet this importance must be put into practice. Some companies already have behaviors and evidence that demonstrate this, however in other cases, this is a process still quite delayed, and as such, it is necessary to change quickly and put sustainability at the center of any decision and later behavior and for this to happen it is necessary to adapt their strategies [54]. For part of the sample, the issue of sustainability is still very much seen as an obligation and it is urgent to change their mindset, it is necessary to demonstrate that as Dangelico and Reuter et al. [50,53] stated the organizations that take into account the theme of sustainability into their decisions and the impacts of their actions on the environment and society may achieve economic returns, competitive advantage, and better performance.

As can be seen in Figure 12, one of the questions in the interviews was how sustainability was integrated into the company. If we look at the branches that contain sustainability, these are linked to the green stems containing the word "strategy", so by analyzing the figure, it is possible to conclude that there is a relationship between the two words. As Drucker [86] underlined, the word "strategy" can be defined as a perspective or way the company expresses its mission and vision, its objectives, its relationship with the market, its resources, and its way of acting making decisions. That said, and confirming the relevance given to sustainability by the sample, it must be integrated into the company's strategy. This leads us to approach another topic: the tools used to formulate the strategy, what they consist of, and how sustainability was or is integrated by the interviewees' companies.

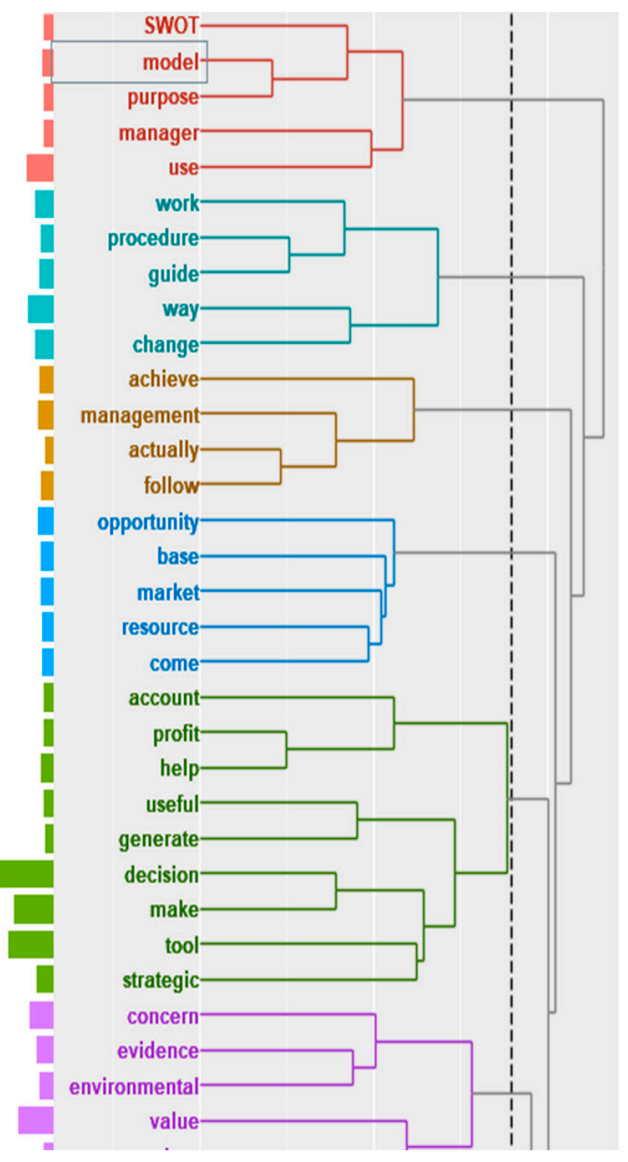

(a)

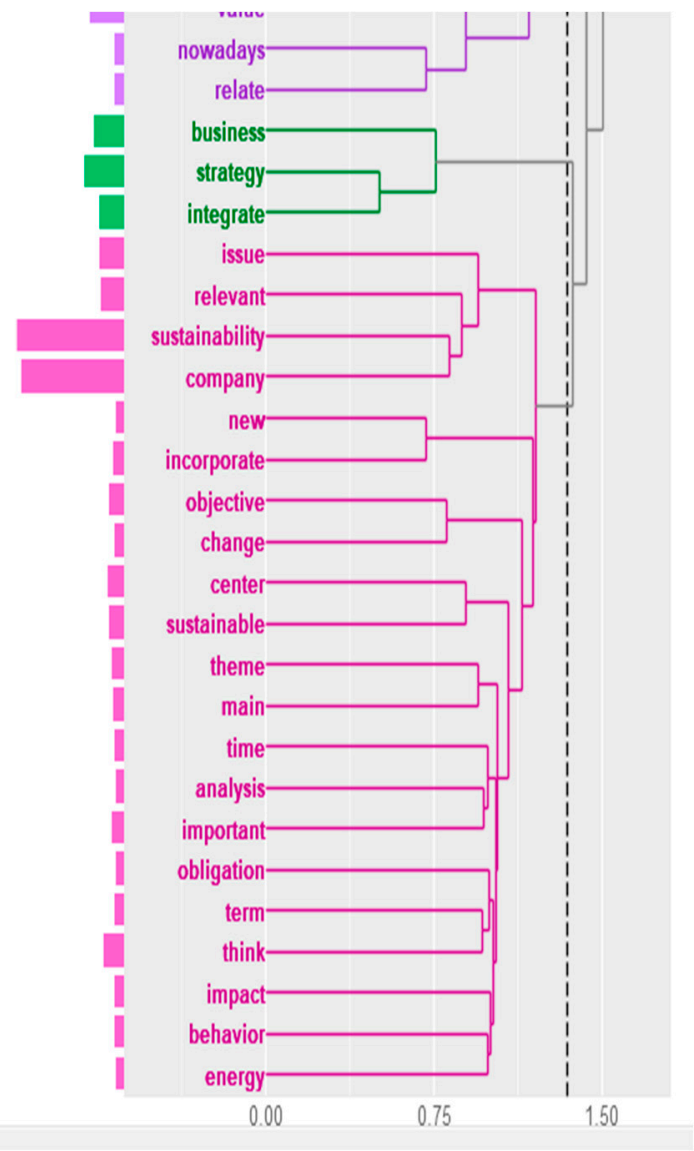

(b)

Figure 12. Text clustering. (a) Output top part (b) Output bottom part. 
One of the great advantages of text clustering is that it allows us to correlate all the themes and understand the links between them. As such, we can see that both the word "sustainability" and "strategy" are also linked to the word "tool". When asked how they integrated sustainability into their companies' strategy, many referred to the creation of a sustainability department that was responsible for this task. However in micro- and medium-sized companies where this department did not exist, when it was necessary to make a decision, the issue of sustainability often did not even enter the equation. Next, the important role that tools can play in the decision making and strategy formulation process was also highlighted. When asked which tools they used in this process, several were mentioned, such as the Pest analysis, the materiality matrix, the play to win model, five forces, and the SWOT analysis. It was also possible to conclude that undoubtedly, the most used tool is a SWOT analysis, for its simplicity, ease of use, accessibility, and because it can be used for any situation and context. Although, it can sometimes lead to subjective and somewhat ambiguous conclusions, but there is no doubt that it is the number one tool [5].

As the environment changes, companies need to realize that they have to change-there are goals more important than just profit maximization, such as practicing sustainable management that allows the company to be prepared for all the risks and vulnerabilities associated with environmental changes such as climate change and resource scarcity [2,31]. The pandemic itself has once again shown the need for companies to adapt their strategies to be prepared to face any circumstance. This sample also shows us that more companies are starting to assume sustainability issues as one of their core values. This is a very relevant issue, and today companies realize that many times when betting on sustainable measures, even though at first, they may lose money in the short term, but in the long term, they will have a much higher return and will be more prepared to face the future [71]. However, one of the big flaws in this chapter for the sample is that today the existing tools do not integrate sustainability as a central and mandatory dimension of them, or those that do are very few and therefore do not help companies develop in this field. They conclude that the number of sustainability tools does not go according to the theme's relevance and, therefore, it is essential to start investing more in this area. More research and work should be done in this area, both academically and professionally, because for most respondents to achieve success, it is necessary to think about the long term, and for this to happen, sustainability should inevitably be one of the pillars of any strategy, something that has not yet happened for what was concluded from the evidence of the interviews. It was also concluded from the interviews that if in the case of macro companies, due to their investment capacity, they can pay to have access to tools that help them in this sense, and when these do not exist, they pay consultants to produce them. In the case of smaller companies, this does not happen and as such, they have great difficulties in acting and developing a strategy based on sustainability, therefore the creation of these new tools can be a great contribution to their strategic planning process. These tools will always be useful and advantageous for all companies, nevertheless, they will be even more essential for micro and medium-sized companies, which in turn do not have the same financial resources as large companies. So, first of all, it is also up to universities and business schools to change the mentality of managers, and it is evident that if there is a willingness to set an agenda in companies, it starts with people and the training they have, so it is vital to instill in people.

Following this path, as we look at the figure, we also see that the word "tool" is linked to the branch of the word "SWOT". As it was possible to realize throughout this data analysis, it was demonstrated from the interviews that it is essential to invest in the creation of tools that insert sustainability as a central dimension of them and that in a certain way help to minimize the impacts that business decisions have on society, planet and environment. For the interviewees, it makes sense to bet on a simple tool, easy to learn and use, without costs for the company, and able to be used in any industry and company dimension [5]. According to Sammut-Bonnici and Gale [87], the objective of SWOT analysis is to use the knowledge that an organization has about its internal and 
external environment, develop strategic options taking into account their impacts, to help formulate the strategy of companies.

To conclude, this data analysis allowed us to realize that in recent years, although issues such as sustainability, environmental awareness, and social responsibility have gone from marginalized concepts to very important for the community in general, it is necessary to continue working to change the mentality of organizations that still see these issues as invalid and unreliable alternatives to achieve their goals. It is essential to change the mindset of profit maximization at any cost and realize that, as Dangelico and Reuter et al. $[50,53]$ referred, companies that are concerned about sustainability and the impact of their actions will naturally reach economic returns, competitive advantage, and better performance, for this to happen companies must understand the need to change to be able to resist in remain competitive over the long term.

\section{Discussion and Findings}

The first question in this research was "How is sustainability integrated into business strategy?" This was answered in each of the 25 interviews, and in all of them, the interviewees first mentioned the importance and relevance that sustainability has or could have in the future of the company and this comes as no surprise because, as Bolis et al. and Chung et al. $[25,66]$ said, although sustainability from a historical perspective has always been a key theme in many topics, it has increasingly gained notoriety and recognition from the business world that increasingly sees this issue as an opportunity to evolve and ensure long-term business success. Regarding the way sustainability is integrated into their strategies, the 25 interviewees gave several answers. Concerning macro companies, because of their investment capacity, sustainability departments were created within the company to help integrate this issue into the company's strategy, creating processes, behaviors, and practices that help the company follow this path. As far as micro and medium enterprises are concerned, for several reasons such as their size and the budget available, they cannot create sustainability departments, so they resort to a set of tools that can help them evaluate the company's performance in this aspect and thus invest in it. However, although the interviewees mentioned some ways in which sustainability is integrated with the company's strategy, they also mentioned that it is necessary to evolve a lot in this direction, it is necessary to have more investment in the issue, to create new tools that integrate sustainability as a central concern and that be able to promote a change in the strategic planning of companies. These will make even more sense in micro and medium enterprises for not having such investment capacity to acquire any tool they need or to pay consultants to create these same tools. This conclusion follows in line with what Annunziata et al. [88] noted when mentioning that companies that care about the subject should bet on the creation and development of tools and capabilities that lead them to focus on sustainability as a way to be and acquire competitive advantage from this.

The second question in this research was "Are the sustainable values of a company relevant enough to influence the decisions taken? How are the consequences of a decision and the impact it may have on society thought through in advance, to avoid damaging business decisions?" This research question encompasses two questions, although both are related, and the respondents' answers to the first question ultimately influenced the second. In general, it was possible to observe that the majority of respondents consider and are aware of the importance that values have in the company and establish a strategic framework based on them, which are often based on sustainable concerns. As such, if they are followed, the decisions that are taken take into account the impact they may have on society, thus avoiding making decisions that harm even the company itself in the future. This confirms what Elkington [54] said, that soon companies would have to change their behavior, the market has changed many in recent years, the same indicators no longer influence it and as such companies need to invest carefully in the development of new strategies capable of effectively adapting to the needs of today's world and thus issues such as sustainability and environmental awareness must be part of them. At the same 
time behaviors should be adopted that in no way negatively affect the environment and society in which we live. However, in other interviews, it was possible to realize that the question of profit maximization is still their main objective and although the values are something important for them, they are often forgotten when, in order to obtain profit, the market demands another kind of behavior. This is something that goes completely against what Robbins [2] said when stated that as the environment changes, companies should not pursue profit maximization as their primary goal, efforts should be made to meet the public's expectations of businesses, to enhance the corporate image, and to practice sustainable management.

Another research question was "For what purpose is the SWOT used by managers of a company? Is it seen only as a useful tool for making decisions that can generate profit in any way, or does it help companies to take other concerns into account when making decisions?" Regarding question number three, it was unanimous to all respondents, and with this possible to conclude, that SWOT analysis remains a widely used tool to help formulate the company strategy. This happens because of its ease of use, accessibility, and ability to analyze any situation. At the same time, it is seen by all as a tool that can be used to support the analysis of competitors, suppliers, markets, products, and services, among other examples, and aims to help the company to acquire competitive advantages over the rest of the market and with this obtain profit [5]. However, it was also possible to observe that when it is necessary to make a more complex and thoughtful decision about certain issues that are a little out of the context of rapid analysis, such as sustainability, it is devalued and is mentioned at the same time that it needs to adapt to new trends in the business market to become more useful to them, agreeing with what Hill and Westbrook [19] said.

Research question number four was, “Today almost all companies have values, which are related to environmental concerns, however, there is evidence that these values are indeed being followed, and what management tool do they use to achieve them?". As previously mentioned, for a part of the sample, the values are associated with environmental and sustainable concerns and these work as a strategic framework for the behaviors and decisions taken by these companies. As a consequence of this, there is evidence that these values are being followed, such as the reduction of GHG emissions, reuse of raw materials and water, investment in renewable energy, eco-friendly facilities, social actions, and betting on the local community, among others. To achieve this, tools such as the materiality matrix, playing to win model, SWOT analysis, and Pest analysis, among others, are used. In other cases, sustainability departments are also created. There is a part of the sample that is in line with what Cuevas [31] said, when he warned that climate change is a reality, the vulnerability of companies will be increasing, and the risks they face will as well, and so it is necessary to adapt the behaviors and demonstrate evidence that companies are concerned about this and are fighting to change the paradigm. In the other interviews, this evidence does not exist for several reasons, but mainly for two. Firstly, because the question of profit continues to be the priority of some of the interviewees' companies and if it is necessary, the values are placed in the background and forgotten. Secondly, because of the lack of tools to help formulate strategies framed in values with sustainable concerns and where the central dimension of it is sustainability, and where the impact of each decision is taken into account, eventually confirming what Yu and Ramanathan [88] said when commenting on the need to create and explore the development of environmental management capabilities capable of giving greater support to companies in this area.

The last research question was, "Is sustainability relevant enough for a company to change the way it works, its procedures and be guided by a tool where sustainability is at the center of everything?" Through data analysis, it was possible to conclude that sustainability has been gaining more notoriety and relevance within organizations in the last few years. Despite this it was concluded from the interviews that the majority of companies continue not to give adequate importance to the subject, and as such, there is no evidence of significant changes in the strategies of the companies. Concepts like 
sustainability and the "Triple Bottom Line" have been more in organizations' daily agenda, and stakeholders are more informed and demanding. It has become an international focus to implement environmental protection activities and social responsibility, and as such any company needs to realize what is going on with their external environment and act quickly [54]. So it is possible to conclude that sustainability has the power to change a company's strategy, procedures, and way of thinking, however, there is still a long way to go. It is imperative to invest in sustainable oriented tools to respond to market needs and remain competitive, confirming what Elkington and Hubbard said when stressing the importance of developing new strategies that would follow the evolution of new trends such as the Triple Bottom Line.

After defining all the findings through the observation of the analysis data and discussion of results we presented and were able to observe in them the need to invest in new tools we present as a corollary the proposal of a new tool called SWOT i. SWOT analysis, as we know it, is a strategic tool that presents the articulation between Strengths, Weaknesses, Opportunities, and Threats to help managers make decisions based on more information with higher accuracy [89].

ISCTE's strategy team developed a new adaptation of this analysis, creating the socalled SWOT i, also called SWOT ISCTE Business School [90]. This consists of elaborating a map based on strategic pillars, with the assumption that the strategy is planned based on the dimension of each one of these pillars. Simultaneously, this tool allows a transversal approach over all the strategic paths, working as a "lens" to visualize the strategy. Each strategic pillar will always be defined according to the organization, and all SWOT analysis will be framed with the strategic pillars considered, forcing us to contextualize the analysis and put it in perspective. In turn, the SWOT i matrix integrates the concern with the scope of sustainability since this is an increasingly relevant issue and present in management decision making. This happens because although organizations have established a strategic framework based on certain values with environmental, social, and economic concerns. In good truth, a more rigorous analysis at the heart of their operational model has left the idea that the decisions of companies often forget these values, defending these actions with the pressure exerted by the markets, which should not happen when we move from thinking to practice. In SWOT $i$, values are placed at the center of strategic formulation, which forces us to consider practices framed in the positive impact that actions may have on society, forcing these two variables to be always present in decision-making.

Finally, it should be noted that whenever SWOT $\mathrm{i}$ is used as a management tool, two questions must always be equated. First of all, if the actions are by the organization's values, and secondly, if they will have a positive or negative impact in environmental, social and economic terms, such as contributing to an increase in climate change, scarcity of resources, social inequality, and increased pollution, among others. This tool can be a giant input in the development and integration of sustainability in the company's strategy since, ultimately, managers are always responsible for making decisions and their consequences [90]. Figure 13 presents the SWOT I framework. 


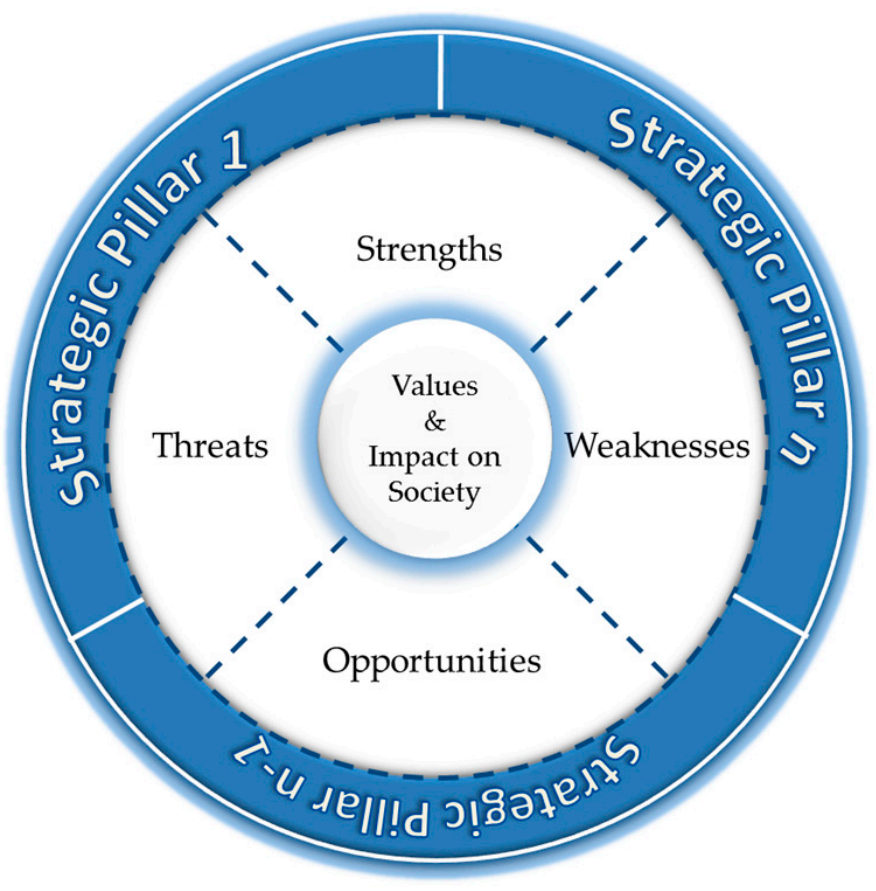

Figure 13. SWOT i.

\section{Conclusions and Future Research Directions}

This article proposes an essential tool for open innovation, firstly integrating the concept of open innovation in the context of both large firms and SME, and secondly to encourage a collaborative approach to innovation by incorporating the dimensions that compose the SWOT i. As such, the new SWOT proposed a collaborative-integrative tool which is the essence of Open Innovation.

From the data analysis and the discussion of the results itself, it was possible to discover some important key findings to mention. Based on our findings, we found that most companies still do not have a sustainable perspective, but rather a short-term one, where the subject of sustainability is constantly forgotten and sometimes not welcomed. The vast majority of companies' strategies do not place the values and impacts that their decisions can have at the center of the strategic formulation.

About sustainability, some events such as climate change, scarcity of resources, the 2008 crisis, the volatility of markets, and the emergence of concepts such as "Corporate Social Responsibility" and Triple Bottom Line were premises and motivations for companies to begin to pay more attention to the issue of sustainability. Although all organizations establish for themselves a strategic framework based on specific values, often based on environmental, social, and economic concerns in good truth, through a more rigorous analysis at the heart of their operational model and the evidence in this regard, it is concluded that many actions of some companies forget these values, often defending the same with the pressure exerted by the markets. Furthermore, although the paradigm is changing, the issue of sustainability is still viewed by many as an obligation and not an opportunity.

For managers, sustainability is very much related to the concept of the Triple Bottom Line, being divided into environmental, economic, and social aspects. When questioned about sustainable behaviors, managers find it difficult to evidence their presence in their strategy. The 2030 Agenda had great importance in the change of mentality and thinking on the part of companies, which began to take sustainability more seriously to contribute to the fulfillment of the Agenda's objectives. The main difficulty encountered by companies in adapting to a new paradigm where sustainability should be at the center of any decision 
and strategy was the lack of tools to help formulate decisions and prepare companies to do so.

There is a greater difficulty for micro and medium enterprises to have access to tools that would help them integrate sustainability into their firms' strategy. Firms nowadays use several tools to formulate their strategies, however, and despite all the criticisms to which SWOT analysis is subject, the SWOT analysis is still one of the most used for its accessibility and ease of use. The great need to invest in tools that integrate sustainability as a central dimension of them and that allow measuring and minimizing the impact that each decision can have on society, planet, and environment and that can thus be used to formulate the strategy of any company.

As this research has shown, despite the growing interest of the community in general with the theme of sustainability, companies still do not have a sustainable perspective, but rather a short-term one, and for many, the implementation of this concept in their strategies is not welcome and is seen as something that slows them down from achieving their intended goals. At the same time, there is still little evidence of behaviors based on values with environmental, social, and economic concerns which follow in a practical way all the interest generated around the subject. If companies' decisions were evaluated, it would be possible to determine that many times they pass these values to the background, excusing themselves with the pressure exerted by the markets.

As it was possible to observe throughout the analysis of data and discussion, although the issue of sustainability is increasingly trendy, it is still seen by some companies as an obligation that often ends up diverting them from the main objective, which is profit maximization. However, it is necessary to clarify that the mentality of companies has to change, and they have to understand that sustainability is thinking about the long-term success of the company, and if they do not think about sustainable management, this will compromise the future of the company.

It was also possible to conclude that one of the biggest difficulties companies face today is the lack of tools to help them integrate sustainability as a central dimension of the whole strategy. In turn, the existence and creation of more tools that incorporate this concept as a central dimension of all decisions will ultimately promote more responsible decision-making, where each decision impact is taken into account, and company managers will have full responsibility for the consequences of the same. The actors of entrepreneurs who suffer most from this are small and medium-sized enterprises that often do not have the financial capacity to invest in certifications and tools to help them develop their work in this field of sustainability.

This must be a simple, practical, and accessible tool to all companies so that there are no excuses for this topic to be taken into account in decision making. From the literature review, it was possible to verify that the SWOT analysis has many flaws and does not consider sustainability a central dimension.

As such and after defining the findings of the research, we present as a corollary a proposal for an adaptation of the SWOT analysis as we know it for SWOT i, also called SWOT ISCTE Business School, which integrates the concern with the scope of sustainability, placing the values at the center of strategic formulation, finally taking into account the impact that each decision may have in environmental, social, and economic terms.

Through SWOT i, it is intended to present a solution to all companies where their future can pass to facilitate the integration of sustainability in each one's strategy.

Author Contributions: Conceptualization, M.P.; methodology, M.P., L.P., R.L.d.C., Á.D. and R.G.; validation, M.P., L.P., R.L.d.C., Á.D. and R.G.; formal analysis, M.P.; investigation, M.P.; resources, M.P.; data curation M.P.; writing—original draft preparation, M.P.; writing—review and editing, M.P., L.P., R.L.d.C., Á.D. and R.G.; supervision, L.P., R.L.d.C., Á.D. and R.G.; project administration, M.P. All authors have read and agreed to the published version of the manuscript.

Funding: This research received no external funding.

Data Availability Statement: Data is contained within the article. 
Acknowledgments: With much appreciation, I would like to thank Leandro Pereira who supported me during my journey with this research.

Conflicts of Interest: The authors declare no conflict of interest.

\section{Appendix A}

Table A1. Interview script.

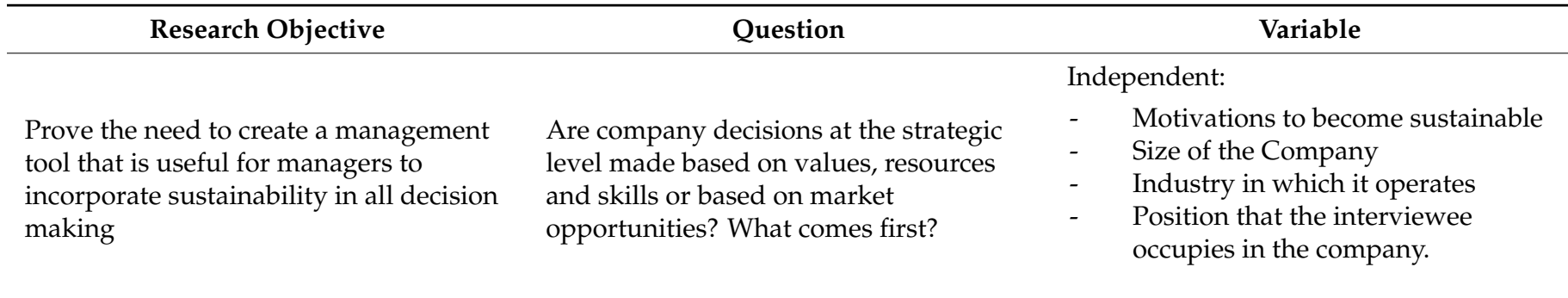

Offer companies' managers a much more complete tool where sustainability is the support for all decisions, and which helps companies to adapt to changes and concerns in the market in a conscious and considered manner.
Is sustainability a relevant issue for the company? Why is it relevant to the company?

\section{Dependent:}

The weigh that the role of sustainability has in the company's strategy Independent:

- $\quad$ The relevance of sustainability for the company

- Industry in which it operates
Offer companies' managers a much more complete tool where sustainability is the support for all decisions, and which helps companies to adapt to changes and concerns in the market in a conscious and considered manner.
What is the context, motivation or premise that led the company to worry about sustainability?

\section{Dependent:}

The weigh that the role of sustainability has in the company's strategy Independent:

- Motivations to become Sustainable

- Industry in which it operates

- $\quad$ Size of the Company

- Sustainability as an obligation

- $\quad$ Sustainability as a business opportunity

\section{Dependent:}

The weigh that the role of sustainability has in the company's strategy Independent:

Incorporate sustainability concerns as a central dimension of SWOT analysis and increasingly present in management decision making.
How is sustainability integrated into the company's strategy?
- $\quad$ Position that the interviewee occupies in the company

- $\quad$ The relevance of sustainability for the company

- Sustainability Issues

- Tools Used to formulate strategies

- $\quad$ Sustainable tools available 
Table A1. Cont.

\begin{tabular}{|c|c|c|}
\hline Research Objective & Question & Variable \\
\hline $\begin{array}{l}\text { Incorporate sustainability concerns as a } \\
\text { central dimension of SWOT analysis and } \\
\text { increasingly present in management } \\
\text { decision making. }\end{array}$ & $\begin{array}{l}\text { When the company discusses strategy, } \\
\text { what are the main sustainability issues } \\
\text { that come into this discussion? }\end{array}$ & $\begin{array}{l}\text { Dependent: } \\
\text { The weigh that the role of sustainability } \\
\text { has in the company's strategy } \\
\text { Independent: } \\
\text { - } \quad \text { Sustainability issues } \\
\text { - } \quad \text { Agenda } 2030 \\
\text { - } \quad \text { Sustainability goals }\end{array}$ \\
\hline
\end{tabular}

\section{Dependent:}

The weigh that the role of sustainability

Incorporate sustainability concerns as a central dimension of SWOT analysis and increasingly present in management decision making.
What evidence, behaviors and rituals does the company's strategy have to drink sustainability at breakfast? has in the company's strategy

Independent:

- $\quad$ Existence of sustainable behaviors

- Sustainability as a business opportunity

- $\quad$ Sustainability as an obligation

- Sustainable tools available
Offer companies' managers a much more complete tool where sustainability is the support for all decisions, and which helps companies to adapt to changes and concerns in the market in a conscious and considered manner.
What practices have changed in the company since this major concern with sustainability? Has the launch of Agenda 30 by the UN and its 17 integrated development objectives resulted in a change of strategy by the company?
Dependent:

The weigh that the role of sustainability has in the company's strategy Independent:

- Industry in which it operates

- $\quad$ Existence of sustainable behaviors

- Agenda 2030
Nowadays almost all companies have values, which are related to environmental concerns, however, there is evidence that these values are actually being followed and what management tool they use to achieve it
How do you see sustainability as a company, as an obligation or business opportunity?

\section{Dependent:}

The weigh that the role of sustainability has in the company's strategy Independent:

- $\quad$ Sustainability as a business opportunity

- $\quad$ Sustainability as an obligation

Dependent:

The weigh that the role of sustainability has in the company's strategy Independent:

What are the greatest difficulties and disadvantages you felt to adapt to a new world paradigm, where sustainability incorporates or should be at the center of all decisions?

\section{- Position that the interviewee} occupies in the company Industry in which it operates

- Disadvantages and difficulties to adopt sustainable behaviors

- Sustainable tools available

\section{Dependent:}

The weigh that the role of sustainability

Does not identify the concern with sustainability as one of the major shortcomings of SWOT analysis, which should be one of the central dimensions of this tool
What sustainability objectives does the company have defined? has in the company's strategy

Independent:

- $\quad$ Size of the company

- $\quad$ Sustainability goals

- $\quad$ Tools used to formulate strategies

- Sustainable tools available 
Table A1. Cont.

\begin{tabular}{|c|c|c|}
\hline Research Objective & Question & Variable \\
\hline $\begin{array}{l}\text { Create a new version of SWOT analysis } \\
\text { that incorporates sustainability concerns } \\
\text { into all decision making and that } \\
\text { subsequently allows for an assessment of } \\
\text { whether the decisions that were made by } \\
\text { managers had these concerns in mind } \\
\text { and the impact that these have in } \\
\text { environmental, social and economic } \\
\text { terms. }\end{array}$ & $\begin{array}{l}\text { When it is necessary to make a strategic } \\
\text { decision, what kind of tool or conceptual } \\
\text { model to use to formulate it? }\end{array}$ & $\begin{array}{l}\text { Dependent: } \\
\text { The weigh that the role of sustainability } \\
\text { has in the company's strategy } \\
\text { Independent: } \\
\text { - } \quad \text { Position that the interviewee } \\
\text { occupies in the company. } \\
\text { - } \quad \text { Size of the company } \\
\text { - The relevance of sustainability for } \\
\text { the company } \\
\text { - Tools used to formulate strategies } \\
\text { - Sustainable tools available }\end{array}$ \\
\hline $\begin{array}{l}\text { Create a new version of SWOT analysis } \\
\text { that incorporates sustainability concerns } \\
\text { into all decision making and that } \\
\text { subsequently allows for an assessment of } \\
\text { whether the decisions that were made by } \\
\text { managers had these concerns in mind } \\
\text { and the impact that these have in } \\
\text { environmental, social and economic } \\
\text { terms. }\end{array}$ & $\begin{array}{l}\text { Do you consider that there is a lack of } \\
\text { tools that incorporate sustainability as a } \\
\text { central dimension in existing strategic } \\
\text { management models? }\end{array}$ & $\begin{array}{l}\text { Dependent: } \\
\text { The weigh that the role of sustainability } \\
\text { has in the company's strategy } \\
\text { Independent: } \\
\text { - } \quad \text { Tools used to formulate strategies } \\
\text { - } \quad \text { Sustainable tools available }\end{array}$ \\
\hline
\end{tabular}

\section{References}

1. Andrews, K.R. The Concept of Corporate Strategy; R. D. Irwin: Homewood, IL, USA, 1980.

2. Robbins, S.P. Essentials of Organizational Behavior; Pearson Higher Ed: Boston, MA, USA, 2013.

3. Agarwal, R.; Grassl, W.; Pahl, J. Meta-SWOT: Introducing a new strategic planning tool. J. Bus. Strat. 2012, 33, 12-21. [CrossRef]

4. Mintzberg, H. The design school: Reconsidering the basic premises of strategic management. Strat. Manag. J. 1990, 11, 171-195. [CrossRef]

5. Coman, A.; Ronen, B. Focused SWOT: Diagnosing critical strengths and weaknesses. Int. J. Prod. Res. 2010, 47, 5677-5689. [CrossRef]

6. Chesbrough, H.W. Open Innovation: The New Imperative for Creating and Profiting from Technology; Harvard Business Press: Brighton, MA, USA, 2003.

7. Christensen, J.F.; Olesen, M.H.; Kjær, J.S. The industrial dynamics of Open Innovation-Evidence from the transformation of consumer electronics. Res. Policy 2005, 34, 1533-1549. [CrossRef]

8. Cooke, P. Regionally asymmetric knowledge capabilities and open innovation. Res. Policy 2005, 34, 1128-1149. [CrossRef]

9. Henkel, J. Selective revealing in open innovation processes: The case of embedded Linux. Res. Policy 2006, 35, 953-969. [CrossRef]

10. Lichtenthaler, U. Leveraging technology assets in the presence of markets for knowledge. Eur. Manag. J. 2008, 26, 122-134. [CrossRef]

11. Vossen, R.W. Research Note-Relative Strengths and Weaknesses of Small Firms in Innovation. Int. Small Bus. J. 1998, 16, 88-94. [CrossRef]

12. West, J.; Vanhaverbeke, W.; Chesbrough, H. Open Innovation: A Research Agenda; Chesbrough, H., Vanhaverbeke, W., West, J., Eds.; Oxford University Press: New York, NY, USA, 2006.

13. Maranto-Vargas, D.; Gómez-Tagle Rangel, R. Development of Internal Resources and Capabilities as Sources of Differentiation of SME under Increased Global Competition: A Field Study in Mexico. Technol. Forecast. Soc. Chang. 2007, 74, 90-99. [CrossRef]

14. Kogut, B.; Shan, W.; Walter, G. The Make-or-Cooperate Decision in the Context of an Industry Network. In Networks and Organizations: Structure, Form and Action; Harvard Business School Press: Boston, MA, USA, 1992.

15. Julien, P.A. Les P.M.E.: Bilan et Perspectives; Economica: Paris, France, 2002.

16. Simard, C.; West, J. Knowledge Networks and Locus of Innovation; Chesbrough, H., Vanhaverbeke, W., West, J., Eds.; Oxford University Press: New York, NY, USA, 2006.

17. Gao, G.-Y.; Peng, D.-H. Consolidating SWOT analysis with non-homogeneous uncertain preference information. Knowl. Based Syst. 2011, 24, 796-808. [CrossRef]

18. Akiyoshi, M.; Komoda, N. An Analysis Framework of Enterprise Documents for Business Strategy Design. In Proceedings of the International Conference on Intelligent Agents, Web Technologies and Internet Commerce, Vienna, Austria, 28-30 November 2005; Volume 1, pp. 65-69.

19. Hill, T.; Westbrook, R. SWOT analysis: It's time for a product recall. Long Range Plan. 1997, 30, 46-52. [CrossRef] 
20. Porter, M. Rethinking competition: Creating tomorrow's advantages. In Rethinking the Future: Rethinking Business Principles, Competition, Control \& Complexity, Leadership, Markets and the World; Gibson, R., Ed.; Nicholas Brealey: London, UK, 1998.

21. Tuncay, M. SWOT Analysis in Strategic Management and a Sample Application in Public. Int. Res. J. York Univ. 2015, 2, $276-301$.

22. Vlados, C. On a Correlative and Evolutionary SWOT Analysis. J. Strategy Manag. 2019, 12, 347-363. [CrossRef]

23. Piercy, N.; Giles, W. Making SWOT Analysis Work. Mark. Intell. Plan. 1989, 7, 5-7. [CrossRef]

24. Wilson, R.M.; Gilligan, C. Strategic Marketing Management: Planning, Implementation and Control; Routledge: Abingdon, UK, 2005.

25. Chung, C.C.; Chao, L.C.; Chen, C.; Lou, S.J. A balanced scorecard of sustainable management in the Taiwanese bicycle industry: Development of performance indicators and importance analysis. Sustainability 2016, 8, 1-21.

26. Barbosa, M.; Castañeda-Ayarza, J.; Ferreira, D.H.L. Sustainable Strategic Management (GES): Sustainability in small business. J. Clean. Prod. 2020, 258, 120880. [CrossRef]

27. Atkinson, G.; Dietz, S.; Neumayer, E. Handbook of Sustainable Development; Edward Elgar Publishing: Cheltenham/Northampton, UK, 2007.

28. Western Cape Education Department (WCED). Our Common Future; World Commission on Environment and Development and Oxford University Press: Oxford, UK, 1987.

29. Kardooni, R.; Yusoff, S.B.; Kari, F.B.; Moeenizadeh, L. Public opinion on renewable energy technologies and climate change in Peninsular Malaysia. Renew. Energy 2018, 116, 659-668. [CrossRef]

30. Cochran, P.L. The evolution of corporate social responsibility. Bus. Horiz. 2007, 50, 449-454. [CrossRef]

31. Cuevas, S.C. Climate change, vulnerability, and risk linkages. Int. J. Clim. Chang. Strat. Manag. 2011, 3, 29-60. [CrossRef]

32. Beermann, M. Linking corporate climate adaptation thinking with resilience thinking. J. Clean. Prod. 2011, 19, 836-842. [CrossRef]

33. Sustainability Report. A Brief History of Sustainability. 2011. Available online: www.sustreport.org (accessed on 12 February 2020).

34. Searcy, C.; Elkhawas, D. Corporate sustainability ratings: An investigation into how corporations use the Dow Jones Sustainability Index. J. Clean. Prod. 2012, 35, 79-92. [CrossRef]

35. World Business Council for Sustainable Development (WBCSD). The business case for sustainable development: Making a Difference towards the Earth Summit 2002 and beyond. Corp. Environ. Str. 2002, 9, 226-235. [CrossRef]

36. Dentchev, N.A. Corporate Social Performance as a Business Strategy. J. Bus. Ethics 2004, 55, 397-412. [CrossRef]

37. Husted, B.W.; Salazar, J.J. Taking Friedman Seriously: Maximizing Profits and Social Performance. J. Manag. Stud. 2006, 43, 75-91. [CrossRef]

38. Phadermrod, B.; Crowder, R.M.; Wills, G.B. Importance-Performance Analysis based SWOT analysis. Int. J. Inf. Manag. 2019, 44, 194-203. [CrossRef]

39. Pesonen, H.-L.; Horn, S. Evaluating the climate SWOT as a tool for defining climate strategies for business. J. Clean. Prod. 2014, 64, 562-571. [CrossRef]

40. Braccini, A.; Margherita, E. Exploring Organizational Sustainability of Industry 4.0 under the Triple Bottom Line: The Case of a Manufacturing Company. Sustainability 2019, 11, 36. [CrossRef]

41. Duque, L.; Costa, R.; Dias, Á.; Pereira, L.; Santos, J.; António, N. New Ways of Working and the Physical Environment to Improve Employee Engagement. Sustainability 2020, 12, 6759. [CrossRef]

42. Tirabeni, L.; De Bernardi, P.; Forliano, C.; Franco, M. How Can Organisations and Business Models Lead to a More Sustainable Society? A Framework from a Systematic Review of the Industry 4.0. Sustainability 2019, 11, 6363. [CrossRef]

43. Chesbrough, H. Business model innovation: It's not just about technology anymore. Strategy Leadersh. 2007, 35, 12-17. [CrossRef]

44. De Bernardi, P.; Azucar, D. Innovative and Sustainable Food Business Models. In Contributions to Management Science; Springer International Publishing: Cham, Switzerland, 2020; pp. 189-221.

45. Stubbs, W.; Higgins, C. Stakeholders' Perspectives on the Role of Regulatory Reform in Integrated Reporting. J. Bus. Ethics 2018, 147, 489-508. [CrossRef]

46. Sachs, J.D.; Schmidt-Traub, G.; Mazzucato, M.; Messner, D.; Nakicenovic, N.; Rockström, J. Six Transformations to Achieve the Sustainable Development Goals. Nat. Sustain. 2019, 2, 805-814. [CrossRef]

47. Diaz-Sarachaga, J.M.; Jato-Espino, D.; Castro-Fresno, D. Is the Sustainable Development Goals (SDG) Index an Adequate Framework to Measure the Progress of the 2030 Agenda? Sustain. Dev. 2018, 26, 663-671. [CrossRef]

48. Sachs, J.; Schmidt-Traub, G.; LaFortune, G. Speaking truth to power about the SDGs. Nature 2020, 584, 344. [CrossRef] [PubMed]

49. Pizzi, S.; Caputo, A.; Corvino, A.; Venturelli, A. Management Research and the UN Sustainable Development Goals (SDGs): A Bibliometric Investigation and Systematic Review. J. Clean. Prod. 2020, 276, 124033. [CrossRef]

50. Dangelico, R.M.; Pujari, D.; Pontrandolfo, P. Green product innovation in manufacturing firms: A sustainability-oriented dynamic capability perspective. Bus. Strategy Environ. 2017, 26, 490-506. [CrossRef]

51. Hofmann, K.H.; Theyel, G.; Wood, C.H. Identifying firm capabilities as drivers of environmental management and sustainability practices-evidence from small and medium-sized manufacturers. Bus. Strategy Environ. 2012, 21, 530-545. [CrossRef]

52. Orlitzky, M.; Schmidt, F.L.; Rynes, S.L. Corporate Social and Financial Performance: A Meta-Analysis. Organ. Stud. 2003, 24, 403-441. [CrossRef]

53. Reuter, C.; Foerstl, K.; Hartmann, E.; Blome, C. Sustainable global supplier management: The role of dynamic capabilities in achieving competitive advantage. J. Supply Chain Manag. 2010, 46, 45-63. [CrossRef]

54. Elkington, J. Cannibals with Forks: The Triple Bottom Line of 21st Century Business; New Society Publishers: Michigan, MI, USA, 1998. 
55. Hubbard, G. Measuring organizational performance: Beyond the triple bottom line. Bus. Strategy Environ. $2009,18,177-191$. [CrossRef]

56. Dias, Á.; Silva, G.M.; Patuleia, M.; González-Rodríguez, M.R. Developing Sustainable Business Models: Local Knowledge Acquisition and Tourism Lifestyle Entrepreneurship. J. Sustain. Tour. 2020, 1-20. [CrossRef]

57. Dias, Á.; Silva, G.M.; Patuleia, M.; González-Rodríguez, M.R. Transforming Local Knowledge into Lifestyle Entrepreneur's Innovativeness: Exploring the Linear and Quadratic Relationships. Curr. Issues Tour. 2021, 1-17. [CrossRef]

58. Robins, F. The Future of Corporate Social Responsibility. Asian Bus. Manag. 2005, 4, 95-115. [CrossRef]

59. Fortin, M.F. Fundamentos e Etapas do Processo de Investigação; Lusodidacta: Loures, Portugal, 2009.

60. Coutinho, C.P. Metodologia de Investigação em Ciências Sociais e Humanas: Teoria e Prática; Edições Almedina: Coimbra, Portugal, 2011.

61. Guerra, I.C. Pesquisa Qualitativa e Análise de Conteúdo. Sentidos e Formas de Uso; Princípia: Lisboa, Portugal, 2006.

62. Goswami, S.; Shishodia, M.S. A Fuzzy Based Approach to Text Mining and Document Clustering. Int. J. Data Min. Knowl. Manag. Process. 2013, 3, 43-52. [CrossRef]

63. Doise, W.; Clémence, A.; Lorenzi-Cioldi, F. The Quantitative Analysis of Social Representations; Harvester Wheatsheaf: London, UK, 1993.

64. Schmitt, N. Quantifying word association responses: What is native-like? System 1998, 26, 389-401. [CrossRef]

65. Massaro, M.; Secinaro, S.; Dal Mas, F.; Brescia, V.; Calandra, D. Industry 4.0 and circular economy: An exploratory analysis of academic and practitioners' perspectives. Bus. Strat. Environ. 2020. [CrossRef]

66. Bolis, I.; Morioka, S.N.; Sznelwar, L.I. When sustainable development risks losing its meaning. Delimiting the concept with a comprehensive literature review and a conceptual model. J. Clean. Prod. 2014, 83, 7-20. [CrossRef]

67. Spiggle, S. Analysis and Interpretation of Qualitative Data in Consumer Research. J. Consum. Res. 1994, 21, 491-503. [CrossRef]

68. Miles, M.B.; Huberman, A.M. Qualitative Data Analysis: An Expanded Source Book, 2nd ed.; Sage: Thousand Oaks, CA, USA, 1994.

69. Barrett, R. Building a Values-Driven Organization: A Whole-System Approach to Cultural Transformation; Butterworth Heinemann: Boston, MA, USA, 2006.

70. Chermack, T.J.; Kasshanna, B.K. The Use and Misuse of SWOT Analysis and Implications for HRD Professionals. Hum. Resour. Dev. Int. 2007, 10, 383-399. [CrossRef]

71. Rahdari, A.H.; Rostamy, A.A.A. Designing a general set of sustainability indicators at the corporate level. J. Clean. Prod. 2015, 108, 757-771. [CrossRef]

72. Bora, B.; Borah, S.; Chungyalpa, W. Crafting strategic objectives: Examining the role of business vision and mission statements. J. Entrep. Org. Manag. 2017, 6, 1-6.

73. Dimitrov, D.K.; Davey, H. Sustainable development: What it means to CFOs of New Zealand. Asian Rev. Account. 2011, 19, 86-108. [CrossRef]

74. Porter, M. What is strategy? Harv. Bus. Rev. 1996, 74, 61-78.

75. Lloret, A. Modeling corporate sustainability strategy. J. Bus. Res. 2016, 69, 418-425. [CrossRef]

76. Johnson, D.; Malhotra, V.; Vamplew, P. More effective web search using bigrams and trigrams. Webology 2006, 3, 1-10.

77. Faber, N.; Jorna, R.; Van Engelen, J. The sustainability of "sustainability". A study into the conceptual foundations of the notion of "sustainability". J. Environ. Assess. Pol. Manag. 2005, 7, 1-33. [CrossRef]

78. Yan, D.; Li, K.; Ye, J. Correlation analysis of short text based on network model. Phys. A 2019, 531, 121728. [CrossRef]

79. Biggs, J. Student Approaches to Learning and Studying; Australian Council for Educational Research: Hawthorn, Australia, 1987.

80. Ramsden, P. Learning to Teach in Higher Education; Routledge: London, UK, 1992.

81. Davies, M. Concept Mapping, Mind Mapping, Argument Mapping: What are the Differences and Do They Matter? High. Educ. 2011, 62, 279-301. [CrossRef]

82. Loebbecke, C.; Wareham, J. The Impact of E-business and the Information Society on Strategy and Strategic Planning. An Assessment of New Concepts and Challenges. Inf. Tech. Manag. 2003, 4, 165-182. [CrossRef]

83. Barney, J.B.; Hesterly, W.S. Strategic Management and Competitive Advantage: Concept and Cases; Pearson/Prentice Hall: Upper Saddle River, NJ, USA, 2006.

84. Costanza, R.; Patten, B.C. Defining and predicting sustainability. Ecol. Econ. 1995, 15, 193-196. [CrossRef]

85. Bezerra, M.C.; Gohr, F.C.; Morioka, S.N. Organizational capabilities towards corporate sustainability benefits: A systematic literature review and an integrative framework proposal. J. Clean. Prod. 2020, 247, 119114. [CrossRef]

86. Drucker, P. The Theory of the Business (Harvard Business Review Classics); Harvard Business Review Press: Massachusetts, MA, USA, 2017.

87. Sammut-Bonnici, T.; McGee, J. Network strategies for the new economy. Eur. Bus. J. 2002, 14, $174-185$.

88. Annunziata, E.; Pucci, T.; Frey, M.; Zanni, L. The role of organizational capabilities in attaining corporate sustainability practices and economic performance: Evidence from Italian wine industry. J. Clean. Prod. 2018, 171, 1300-1311. [CrossRef]

89. Helms, M.M.; Nixon, J. Exploring SWOT analysis—Where are we now? J. Strag. Manag. 2010, 3, 215-251. [CrossRef]

90. Pereira, L.; Lopes da Costa, R.; António, N. Estratégia Organizacional: Do Estado da Arte à Implementação Prática; Descrição Detalhada da Publicação: Lisboa/Almeidina, Portugal, 2019. 